\title{
The Flora of Lord Howe Island.
}

\author{
BY \\ W. BOTTING HEMSLEY, F.R.S., F.L.S., \\ Principal Assistant in the Herbarium, Royal Gardens, Kew.

\section{INTRODUCTION.}

T ORD Howe Island is one of the most singular, most 1 beautiful, and most interesting islands in the world; interesting alike on account of its position, its conformation, and its vegetation. It is situated in $31^{\circ} 30^{\prime} \mathrm{S}$. lat. and $159^{\circ}$ E. long., and it is about 300 miles from Port Macquarie, New South Wales. It was discovered by Lieut. Henry Lidgbird Ball, Commander of the Supply, in I 788 , when on a voyage from Port Jackson to Norfolk Island, for the purpose of founding a convict settlement there, under the governorship of Lieutenant King. It was named after Lord Howe, the First Lord of the Admiralty at the time; and on the return voyage it was surveyed, the results being published in Phillip's and Hunter's accounts of the establishment of the colonies at Port Jackson and Norfolk Island. There are also some references to Howe Island in Surgeon-General White's journal, which contains so much about the natural history of Port Jackson ; but, strange to say, the only statement with regard to the vegetation is that the island was very barren.

There is a chart and a view of the island in Governor

1 The same name was given to a group of islands to the north-east of the Solomon Islands by Captain Hunter, and to one of the islands in the Society group by Captain Wallis.

[Annals of Botany, Vol. X. No. XXXVIII. June, I896.] 
Phillip's book, and also a view of the very curious rock, called Ball's Pyramid, which is situated ten miles south-east of the main island. "They found no fresh water on the island. but it abounds with Cabbage-Palms, Mangrove and Manchineal trees, even up to the summits of the mountains.'

Before proceeding to the history of the botanical exploration of the island, it may be well to give some particulars of its size, conformation, climate, and geology, for which I am mainly indebted to a report by the Hon. J. Bowie Wilson, issued in 1882 .

The island is somewhat crescent-shaped, and about seven miles long, with an average width of one mile. On the west side, within the crescent, there is a coral reef, enclosing a lagoon, in which small vessels can safely anchor. There are several adjacent islets, the principal of which are, Mutton Bird Isle, on the east side of the main island; Gower Isle, at the south end; Goat Isle, in the lagoon, and the Admiralty Isles, a small group to the north; not to be confused with the Admiralty Islands in the New Britain archipelago, to the east of New Guinea.

The main island consists of three elevated basaltic masses, connected by low-lying ground of blown coral-sand formation. At the southern end are two circular, steep, flat-topped hills, called Mount Gower and Mount Lidgbird, respectively 2,840 and 2,504 feet high. The central and northern masses of basalt are very much smaller and less elevated, being in the highest parts only 400 to 700 feet high. There is no lack of fresh water in the island; and the soil is sufficiently fertile to support a luxuriant vegetation, even to the summits of the hills. On the low-lying lands the soil is described as exceedingly rich, especially where it has been derived from decomposed basalt, mingled with calcareous sand and decayed vegetable matter. The climate, too, is said to be delicious and equable, with sufficient rainfall; and the vegetation is quite tropical in character.

When first discovered, Lord Howe Island was uninhabited, but thenceforward numerous whaling-ships resorted there for 
wood and water; and goats and hogs were soon introduced. In the early days of the Port Jackson settlement, when they were often hard up for food, they used to send to the island for turtles. White relates that the Supply on her return from her first voyage to Norfolk Island carried eighteen turtles from the island, the smallest of which did not weigh less than I5O pounds. The Palms, too, were soon much reduced in numbers, being destroyed for the sake of the terminal bud, or 'cabbage,' as it was commonly called, which was the only available vegetable. In 1833 or 1834 half a dozen persons settled on the island, but the occupation was not a permanent one.

The first definite information respecting the flora was obtained by John MacGillivray and William Milne, naturalists to H. M. S. Herald, which ship first visited the island in 18.53 . The former was a zoologist, and the latter a gardener, who was an excellent collector but a very poor scholar, consequently his lengthy manuscript journal in the Kew library contains almost nothing worth transcribing. Both collected and dried plants and transmitted them to Kew; yet they failed to get the Palms and many of the other endemic plants. MacGillivray's list comprises thirty-six species, and Milne's about sixty, including some cellular cryptogams. The vascular plants of these and later collectors are included in Bentham's Flora Australiensis and Mueller's Fragmenta Phytographiae Australis. MacGillivray contributed a short account of their stay in the island to Hooker's Kew Journal of Botany, from which it appears that there were then three families and two or three other persons living in the island. He noted the affinity of the flora with that of Norfolk Island and Australia; also the absence of Coniferae, and the presence of dense forests of Palms. As his observations on the flora are the earliest made by any person possessing the least knowledge of botany, I make the following extract:-

'Here and there is an occasional enormous Banyan-tree, with its singular root-like supporting stems, and some plants of a Pandanus, or 'Tent-tree,' as it is here called. My old 
friend, Flagellaria indica, as usual, is not tied down to the quiet orderly growth of its fellows in the vegetable kingdom, but aspires to paying rambling visits to the summits of the neighbouring trees. What with this, and the Palms, and the Banyans, and the Screw-Pines, and the clumps of parasitical Orchideae and Ferns, the forest scenery struck me as having quite a tropical aspect ; and when, after passing some cleared land in a neglected state, overrun with weeds (among which were the ubiquitous Stellaria media and Sonchus oleraceus), and some patches of rude cultivation, we came in sight of the establishment of one of the settlers. The palm-slab built and palm-leaf thatched cottage and outhouses reminded me of a Malayan or Javanese hamlet. Several species of Ferns occurred here. Besides a Cyathea, with a caudex ten or twelve feet in length and six inches in diameter, a very handsome Hypolepis, a Pteris, a Litobrochia, and a widelyspreading Asplenium, with fronds six feet in length, were plentiful. A long straggling Polypodium, and a Pleopeltis, ran over rocks and up the trunks of trees. We saw enormous clumps of a Platycerium, high up on the Banyans, and got fine specimens from a tree which had been blown down.'

In June, I 869, Mr. C. Moore, the Director of the Sydney Botanic Garden, spent three days in the island, and collected about 150 species of plants, most of them, unfortunately, without either flower or fruit. A set comprising Ioo species was communicated to Kew. Mr. Moore drew up a report on the vegetation, to which was appended a preliminary list of the plants.

In many cases only generic names are given; and in a few instances the specific determinations have since been corrected, either by Moore himself, or by other persons who have studied the plants. I have considered it necessary to cite such erroneous names as synonyms in the following enumeration, because this report, being the best account of the vegetation extant, is likely to be referred to and the names taken up elsewhere. I have been able to verify almost every one of the corrections of the doubtful deter- 
minations. This report is so rare that I think I shall be doing a good service by giving almost in full the paragraphs relating to the vegetation.

'Every part of the island is covered with a dense vegetation, the undergrowth being kept comparatively clear by pigs and goats, which are allowed to roam at large. These crop off the lower branches of the trees, and in too many instances, it is feared, have destroyed the smaller kinds of plants altogether. The absence of undergrowth, and the very remarkable scarcity of Ferns and Orchids, in the lowest and richest parts of the island, would indicate a dryness of climate which is not the case, as a drought of any great continuance is seldom or never experienced here, rain being said to be frequent and abundant at all seasons. While the want of undergrowth may be accounted for by the action of pigs and goats, yet the rarity of the classes of plants referred to cannot be so readily explained. Thus, in the rich low flats, extending upwards of three miles, where the trees are thickest and most lofty, only one Orchid-Dendrobium gracilicaule, F. Muell.and five or six Ferns were all that were observed, and these sparingly. At the end of this flat ground towards the east, in gullies near the base of the mountains, and up to their very summit, Ferns increase in numbers, both as regards genera and species. The presence among these of Trichomanes and Hymenophyllum would dissipate the notion of a very dry atmosphere, and prove at least a greater abundance of moisture in proximity to the mountains than occurs elsewhere. A second and taller species of Dendrobium was gathered at a rather high elevation. This, with the former, and a species of Sarcochilus, found sparingly upon trees growing on the hilly sides, at the other end of the island, were the only representatives of the family of Orchideae noticed. One of the most remarkable features of the vegetation is the prevalence of Palms, of which there are four species, all of which appear to be as yet undescribed. Two of these, called by the settlers respectively, "Thatch Palm" and "Curlyleaved Palm" [Howea], and both sometimes "Cabbage-Palms," 
are very general, and most abundant ${ }^{1}$. They reach to a height of at least I,000 feet on the side of Mount Lidgbird, at which point their place is supplied by another very distinct species, of a noble appearance, called the "Umbrella Palm" [Hedyscepe], from its compact, gracefully-drooping, arched, dome-like, pinnate fronds. The zone of this plant is of limited extent, as it does not reach within some hundreds of feet of the top of the mountain, where a dwarf species [Clinostigma], not more than six feet high, also with pinnate fronds, and altogether different from any of the others, occurs in large quantities.

"The Pandanus, or "Screw-pine," of which there appear to be two species, marks the vegetation in a peculiar manner wherever it occurs. One species, known to the settlers as the "Tent-tree," Pandanus Forsteri, grows plentifully in some parts of the flats, but is more general on the mountain sides, increasing in number as they ascend, and attaining to an elevation of at least 2,000 feet. This often grows to a height of over thirty feet, the lower half of which is usually constituted of spreading stem-like roots, which proceed from the main stem at various heights, and as the earlier roots perish, in a manner almost corresponding with the production of those from above, a clear space is thus left beneath, the plant being supported by these root-props, having a tent-like resemblance. The most remarkable plant, however, upon the island, is a species of Ficus, and the only one of the genus found here. Along the whole extent of the flat and richest ground, on the south-west side, this noble tree grows in large numbers-very rarely in exposed situations-but marks distinctly an inner zone of vegetation, being protected on every side by belts of trees of various descriptions. It possesses to an extraordinary degree the branch-rooting characteristics of the famous "Banyan" of India.

"The trees of most frequent occurrence throughout the

1 These elegant palms are cultivated by thousands in this country now, as they are slow growing and retain their beauty for a long time in pots. In the Palm House at Kew is a handsome fully-developed specimen of H. Forsteriana.-W. B. H. 
island were Hibiscus Patersonii, Myoporum acuminatum, called "juniper," and Ochrosia elliptica; all most abundant near the coast, and forming for the most part the outer or most exposed belt, the latter being, it is supposed, the "Manchineal" mentioned by Lieutenant Ball, the discoverer of the island. These and a species of Acronychia, Hemicyclia australasica, the latter remarkable for its bright-coloured foliage and red-coloured fruit, Olea paniculata, Achras costata, Pisonia Brunoniana, Baloghia lucida, and a species of Tetranthera-constitute at least three-fourths of the tree-vegetation. Climbing-plants were represented by Marsdenia rostrata, Stephania hernandifolia, Smilax latifolia, Flagellaria indica, Ipomoea palmata, Ipomoea Pes-caprae, Tecoma australis, and Canavalia obtusifolia. Among the more rare and interesting plants, special mention may be made of a magnificent species of Dracophyllum discovered by R. D. Fitzgerald, in a valley between the two highest mountains, called Erskine Valley. This magnificient species (perhaps the finest of the genus) being new, will henceforth bear the name of its discoverer, Dracophyllum Fitzgevaldii, who describes it as "a tree between forty and fifty feet high, with a trunk at least two feet in diameter. It produced the leaves in tufts at the ends of the branches, and panicles of flowers of a reddish-white colour, from nine inches to a foot long, springing from the centre of the tufts. Altogether it had a strange appearance, growing in a rambling way, the small branches forking like a Pandanus, the whole tree having the semblance of producing young Pine-apple plants." A beautiful species of Randia ( $R$. macrophylla, Moore), with large bright-shining foliage and stipules, was met with in several parts of the island. A singular plant of the Mistletoe kind, Viscum opuntioides, found also in Norfolk Island, was observed growing in considerable quantities, but only upon two kinds of trees, Hemicyclia and Elaeodendron. A most offensivesmelling plant (Coprosma putida) was met with both on the high and low grounds. A large Iridaceous plant ${ }^{1}$, termed

1 At the present time (May, 1896 ) there is a fine plant of this at the south end 
the "Wedding Flower," was found sparingly in two or three situations. Of this seed-vessels only were obtained, but the flowers were described as being very beautiful. The leaves were upwards of six feet long, and from two to three inches in breadth. In appearance it resembles a large species of Moraea, [M. Robinsoniana] but will probably prove to be a new genus.

- At the mouth of a creek or small rivulet, near the base of Mount Gower, Aegiceras fragrans was observed for the first and only time, although it is said that this or some other kind of Mangrove grows where another rivulet enters the sea. Along the coast on the northern side Crinum pedunculatum, Funcus maritimus, Rhagodia Billardierii, Senecio insularis, Mesembryanthemum aequilaterale, Ipomoea Pes-caprae, and Canavalia obtusifolia, occupied for the most part the sandy ridges raised by the wind from the beach. Curiously enough, on this, the warmest side of the island, the trees and shrubby plants appeared to suffer more from exposure to the sea than they did on the opposite or southern side. There, especially, Hibiscus Patersonii, Ochrosia elliptica, and Myoporum acuminatum, which, as has been before observed, constitute the principal part of the outer belt of tree vegetation, grew to be both good sized and well formed, whilst here they were reduced to a low-sized and nearly impenetrable scrub, the more so as they were usually intermixed with Guilandina Bonducella, a sub-climbing prickly shrub. In some parts of the interior, Verbena bonariensis, Ricinus communis, Solanum laciniatum, Sonchus oleraceus, and other smaller kinds, evidently foreigners to the soil, had, from neglect, taken almost entire possession of fine tracts of cleared ground, and had become, in other parts, very troublesome weeds.

'Two interesting arborescent Ferns (species of Alsophila) were observed in a small valley near the base of Mount Gower, growing in company with Alsophila excelsa. In

of the Succulent House at Kew. It is between seven and eight feet high, and has about a dozen vigorous flower-stems.-W. B. H. 
the same locality with these, Trichomanes meifolium, var. Bauerianum, grew plentifully. Another fine species of Trichomanes, as well as Lomaria capensis and Hymenophyllum tunbridgense, were brought from the top of the mountain by one of the settlers, who stated that they all grew there in the greatest profusion, as well as a large and beautiful moss, more than a foot in height [Spiridens Muelleri].'

In addition to the collections of Lord Howe Island plants already mentioned, Kew possesses two others, namely, one of sixty species, labelled 'Eclipse Expedition,' communicated by Mr. C. Moore in 1872 ; and one of ninety-two species, labelled 'Fullagar's Expedition,' purchased through Sir F. von Mueller in I874. The following year Mueller published a bare list of all the plants known to him from the island, excluding evidently introduced species. This list comprises $\mathrm{I} 82$ species of vascular plants.

The Commission, headed by the Hon. J. B. Wilson, which visited the island in I882, included Mr. J. Duff, of the Sydney Botanic Garden, who furnished a report on the vegetation, from which we learn that the endemic Palms and Tree-ferns were rapidly disappearing, and the latter were in danger of becoming extinct if their removal was not absolutely prohibited. And from some cause not ascertained, many of the fine Banyan trees were dead or dying. It is to be hoped, however, that the recommendations of the Commission that the Colonial Government should not grant further leases, and should take measures to preserve the native vegetation, have been adopted. Among the photographs which embellish $\mathrm{Mr}$. Wilson's report is one of a living Banyan, said to cover an area of three acres! But sad to relate, in many of the other photographs dead trees stand out prominently as white skeletons.

Mr. Duff's report consists mainly of notes on the predominant trees of the island, and such of these notes as are of sufficient interest I have embodied under the respective species in the enumeration.

Some of the party visited the Admiralty Islets, and also 
succeeded in landing on Ball's Pyramid, which is about I, 800 feet high, with a base of only three-quarters of a mile in its greatest diameter. Mr. Duff mentions that the plants collected were presented to him, but he gives no names. I have written to Mr. Moore for information on this point, and since writing $I$ have discovered that it has long been his intention to write a Flora of Lord Howe and Norfolk Islands. Of course the present purely geographical paper cannot stand in the way of a descriptive work ${ }^{1}$.

\section{ENUMERATION OF ALL THE INDIGENOUS VASCULAR PLANTS KNOWN TO INHABIT THE ISLAND.}

\section{RANUNCULACEAE.}

1. Clematis glycinoides, DC. Syst. i, p. I45; Benth. Fl. Austral. i, p. 7 ; F. Muell. Fragm. ix, p. 76 ; x, p. 2.

Common in New South Wales and Queensland, and Sir F. von Mueller reports it from New Caledonia.

\section{MAGNOLIACEAE.}

2. Drimys Howeana, F. Muell. Fragm. vii, p. 17.

Drimys insularis, Baill. ex F. Muell. Fragm. ix, p. 76 .

Very closely allied to D. semicarpifolia, F. Muell., a native of Queensland.

This genus is common to the South American and Australasian regions, and extends to Western Polynesia and the Malay Archipelago, northward to the Philippine Islands.

Moore, in his sketch of the vegetation of the island, cites a second unnamed species, but all the specimens seen belong to one species.

${ }^{1}$ Since writing the above I have heard from Mr. Moore to the effect that he had relinquished the idea; but he hopes yet to be able to send a collector to thoroughly botanize the island, as he believes there is more to be done, and should he succeed he would communicate the materials to me. He failed, however, to answer my question respecting the plants of Ball's Pyramid. 


\section{MENISPERMACEAE.}

3. Stephania discolor, Spreng. Syst. iv, Cur. Post. p. $3 \mathrm{I} 6$. Stephania hernandifolia, Walp. Rep. i, p. 96 ; Benth. Fl. Austral. i, p. 57; Maxim. Diag. P1. Nov. v, t. 2 ; F. Muell. Fragm. ix, p. 76 .

Australia, Polynesia, and tropical Asia and Africa.

\section{Cruciferae.}

4. Lepidium foliosum, Desv. Journ. Bot. iii (I 8 I 4), pp. I64, I 80 ; Benth. Fl. Austral. i, p. $86 ; \cdot$ F. Muell. Fragm. ix, p. 76 .

Inserted on the authority of Sir F. von Mueller, though the plant from Lord Howe Island in the Kew Herbarium bearing this name is evidently the same as that referred to L. ruderale in the Flora Australiensis. $L$. foliosum is generally spread in extratropical Australia and in Tasmania.

5. Lepidium ruderale, L. Sp. Pl. p. 645 ; Benth. Fl. Austral. i, p. 86 ; Reichb. Ic. Fl. Germ. ii, t. Io ; Engl. Bot. ed. iii, t. I 54 .

The insular variety is an almost shrubby one, which is widely spread in Australia, and very different in appearance from that common in the northern hemisphere.

\section{Violaceae.}

6. Hymenanthera latifolia, Endl. Prod. Fl. Norf. p. 70 ; F. Muell. Fragm. ix, p. 77 ; x, p. 82.

Norfolk Island.

This is probably a variety of $H$. Banksii, R. Br., which would also include the New Zealand H.crassifolia, Hook. f., and Sir F. von Mueller has already united them. In this sense the geographical area of the species further includes Tasmania, South Australia, Victoria, and New South Wales.

\section{Bixineae.}

7. Xylosma ovatum, Benth. Fl. Austral. i, p. I08 ; F. Muell. Fragm. ix, p. 6o, et p. 77 .

Phoberos? C. Moore, Rep. p. 3 .

New South Wales and Queensland. 
VII. Pittosporaceae.

8. Pittosporum erioloma, C. Moore \& F. Muell. in F. Muell. Fragm. vii, p. I 39 ; ix, p. 77.

Endemic.

\section{ViII. Guttiferae.}

9. Calophyllum inophyllum, L. Sp. Pl. p. $5^{1} 3$; Benth. Fl. Austral. i, p. 183 ; C. Moore in Trans. Roy. Soc. N. S. Wales, v, p. 3I ; Wight, Ic. t. 77 .

Tropical Australia, Polynesia, Malaya, India, and Mascarene Islands.

There is no specimen of this in the Kew Herbarium from the island, although it is included in the manuscript list of the plants presented by Mr. Moore. Nor is it in Sir F. von Mueller's list.

\section{Malvaceae.}

10. Hibiscus diversifolius, Jacq. Ic. Pl. Rar. t. 55I ; Coll. ii, p. 307 ; Benth. Fl. Austral. i, p. 213; C. Moore, Rep. p. 3 ; F. Muell. Fragm. ix, p. 77 ; Bot. Reg. t. 38I.

Tropics of the Old World.

11. Hibiscus tiliaceus, L. Sp. P1. p. 694; Benth. Fl. Austral. i, p. 218.

Paritium tiliaceum, St. Hil. Fl. Bras. Mer. i, p. 256; F. Muell. Fragm. ix, p. 77 ; Wight, Ic. Pl. t. 7 .

Tropics of the Old World, in islands and maritime districts.

12. Lagunaria Patersoni, G. Don, Gen. Syst. i, p. 485 ; Benth. Fl. Austral. i, p. 218 ; F. Muell. Fragm. ix, p. 77.

Hibiscus Patersoni, DC. Prod. i, p. 454 ; Andr. Bot. Rep. t. 286.

Queensland and Norfolk Island.

This is in Mueller's list, but there is no specimen from the island at Kew. Moore states that it was one of the most frequent trees.

Mueller (Fragm. ix, p. 77) includes the genus Elaeocarpus (Tiliaceae) : 'Elaeocarpus foliatione, quae tantum nota, E. foveolalo similis,' but there is no specimen in any of the collections received at Kew. 


\section{Geraniaceae.}

13. Pelargonium, australe, Jacq. Eclog. P1. t. Ioo; Sweet, Geran. t. 68 ; Benth. Fl. Austral. i, p. 298 ; F. Muell. Fragm. ix, p. 77 .

Extratropical Australia, Tasmania, New Zealand, Tristan d'Acunha, and South Africa.

This species, as here limited, presents a wide range of variation.

\section{OXALIDACEAE.}

14. Oxalis corniculata, L. Sp. Pl. p. 435 ; Benth. Fl. Austral. i, p. 301 ; F. Muell. Fragm. ix, p. 77 ; Reichb. Ic. Fl. Germ. v, t. I99; Wight, Ic. t. I8 ; Engl. Bot. ed. iii, t. 3 II.

This is now very widely dispersed, but how far its present area is due to human agency is uncertain.

\section{Rutaceae.}

15. Melicope contermina, C. Moore \& F. Muell. in F. Muell. Fragm. vii, p. I44; ix, p. 77 .

Evodia contermina, C. Moore \& F. Muell. loc. cit. vii, p. I44. Endemic.

Very near the New Zealand M. ternata, Forst.

16. Evodia polybotrya, C. Moore \& F. Muell. in F. Muell. Fragm. vii, p. I43; ix, p. 77 .

Endemic.

17. Zanthoxylum Blackburnia, Benth. Fl. Austral. i, p. $3^{6} 3$; F. Muell. Fragm. vii, p. sine nomine specifico.

Zanthoxylum Howeanum, F. Muell. Fragm. ix, p. 77, sine descriptione.

Blackburnia pinnata, Forst. Prodr. Fl. Ins. Austral. p. Io; Char. Gen. t. 6 ; Endl. Prodr. Fl. Norf. p. 88.

Norfolk Island and perhaps New Caledonia.

18. Acronychia Baueri, Schott, Fragm. Rutac. p. 5, t. 3 ; Benth. Fl. Austral. i, p. 366 ; F. Muell. Fragm. ix, p. 77.

New South Wales and Queensland. 


\section{XiII. Meliaceae.}

19. Dysoxylum Fraseranum, Benth. Fl. Austral. i, p. $3^{81}$; F. Muell. Fragm. ix, p. 77 .

Hartighsea Fraserana, A. Juss. in Mem. Mus. Par. xix, p. 262, t. 15 .

New South Wales and Queensland.

\section{Celastrineae.}

20. Elaeodendron australe, Vent. Jard. Malm. t. I I 7 ; Benth. Fl. Austral. i, p. 402 ; F. Muell. Fragm. ix, p. 77.

New South Wales, Queensland, and North Australia.

21. Elaeodendron melanocarpum, F. Muell. Fragm. iii, p. 62 ; Benth. Fl. Austral. i, p. 403.

North Australia and Queensland.

XV. Sapindaceae.

22. Cupania anacardioides, A. Rich. Sert. Astrol. p. 33, t. I3; Benth. Fl. Austral. i, p. $45^{8}$; F. Muell. Fragm. ix, p. 77 .

New South Wales, Queensland, and North Australia.

A plant of this affinity is included in Mueller's list as 'Nephelium a N. semiglauco [Cupania semiglauca] fructibus majoribus diversum ;' but there is not a second species from the island in the Kew Herbarium. Tate includes the Australian $N$. semiglaucum in his list without the sign of doubt.

23. Atalaya coriacea, Radlk. in Sitzb. Akad. Wiss. Muench. 1878, p. 326 ; F. Muell. Census Austral. Pl. ed. II, p. 41. Atalaya multiflora, Benth. Fl. Austral. i, p. 463, pro parte. Endemic.

24. Dodonaea lanceolata, F. Muell. Fragm. i, p. 73 ; ix, p. 77 ; Benth. Fl. Austral. i, p. 475 .

Dodonaea viscosa, C. Moore, Rep. p. 3, vix Linn.

South Australia, New South Wales, Queensland, and North Australia. 


\section{LEGUMINOSAE.}

25. Carmichaelia exul, F. Muell. Fragm. vii, p. I26; ix, p. 77 .

Endemic.

With this exception the genus Carmichaelia is restricted to the main islands of New Zealand, where the species are numerous and some of them common. C. exul is a shrub ten to fifteen feet high, and is singular in the flower-bearing branches being leafy.

26. Mucuna gigantea, DC. Prod. ii, p. 405 ; Benth. Fl. Austral. ii, p. 254 ; Hook. Bot. Misc. ii, p. 351, Suppl. t. 14 ; F. Muell. Fragm. ix, p. 77.

Tropical Asia, Australia, and Polynesia.

27. Canavalia obtusifolia, DC. Prod. ii, p. 404 ; Benth. Fl. Austral. ii, p. $25^{6}$; Benth. in Mart. Fl. Bras. xv, I, t. 48 ; F. Muell. Fragm. ix, p. 77 .

Widely spread in tropical Australia, Polynesia, Asia, Africa, and America, chiefly near the sea.

28. Vigna lutea, A. Gr. Bot. Wilk. Exped. i, p. 454; Benth. Fl. Austral. ii, p. 259 ; F. Muell. Fragm. ix, p. 77 ; Sinclair, Fl. Hawaii, t. 28.

Tropics of both hemispheres.

29. Sophora tetraptera, J. Mill. Ic. Pl. t. I ; Hook. f. Handb. N. Zeal. Fl. p 52 ; Kirk, For. Fl. N. Zeal. tt. 50-52; F. Muell. Fragm. ix, p. 77 ; Hemsl. Rep. Voy. Chall. Bot. i, pt. 3, p. $3^{2}$.

Edwardsia chrysophylla, C. Moore, Rep. p. 3.

New Zealand, South America, and Easter Island.

30. Caesalpinia Bonducella, Fleming, in As. Res. xi (1810), p. I59; Mart. Fl. Bras. xv, II, t. 2 I.

Guilandina Bonducella, L. Sp. Pl. p. 545 ; Benth. Fl. Austral. ii, p. 276 ; F. Muell. Fragm. ix, p. 77 ; Lam. Illustr. t. 336.

Very widely spread in maritime districts in the tropics. 
XVII. Saxifragaceae.

31. Colmeiroa carpodetoides, F. Muell. Fragm. vii, p. I49; ix, p. 77 .

An endemic genus most nearly related to the monotypic New Zealand Carpodetus.

\section{MYRTACEAE.}

32. Leptospermum flavescens, Sm. in Trans. Linn. Soc. iii (1797), p. 262 ; Benth. Fl. Austral. iii, p. 104; F. Muell. Fragm. ix, p. 77 ; Bot. Mag. t. 2695 .

Leptospermum amboinense, Blume, Bijdr. p. I Ico; Hook. f. Fl. Brit. Ind. ii, p. 464 .

Tasmania, Victoria, New South Wales, and Queensland. Also in Malacca and the Malay Archipelago.

33. Melaleuca ericifolia, Sm. in Trans. Linn. Soc. iii (I 797), p. 276 ; Benth. Fl. Austral. iii, p. I59; F. Muell. Fragm. ix, p. 77 ; Sm. Exot. Bot. t. 34 .

Tasmania, Victoria, South Australia, New South Wales, and Queensland.

34. Acicalyptus Fullagari, F. Muell. Fragm. viii, p. I5; ix, p. 77 .

Eugenia, sp. C. Moore in Trans. Roy. Soc. N. S. Wales, v. p. $3^{\mathrm{I}}$.

Endemic.

Four other species are known; three inhabit Fiji and one New Caledonia.

35. Metrosideros nervulosa, C. Moore \& F. Muell. Fragm. viii, p. I5; ix, p. 77 .

Endemic.

36. Metrosideros polymorpha, Gaudich. in Freyc. Voy. Bot. p. 482 , t. 85 ; F. Muell. Fragm. ix, p. 77 ; Kirk, For. Fl. N. Zeal. t. I 9 ; Hillebr. Fl. Haw. p. I 25.

Metrosideros villosa, Sm. in Trans. Linn. Soc. iii ( $\left.179^{-}\right)$, p. 268.

Kermadec Islands, New Caledonia, Tonga, Fiji, Society, Marquesas, Sandwich, and Pitcairn Islands. A characteristic tree almost all over 
Polynesia. The genus is represented by about twenty different species in Australia, New Zealand, and Polynesia, two or three in the Malay Archipelago, and one in South Africa.

XIX. Passifloraceae.

37. Passiflora Herbertiana [Ker-Gawl] in Bot. Reg. t. 737 ; Benth. Fl. Austral. iii, p. 3I I F. Muell. Fragm. ix, p. 77.

New South Wales and Queensland.

\section{Cucurbitaceae.}

38. Sicyos angulatus, L. Sp. Pl. p. IOI3; Benth. Fl. Austral. iii, p. 322 ; F. Muell. Fragm. ix, p. 77.

A widely-spread weed, common in Australia, New Zealand, and Polynesia.

\section{Ficoideae.}

39. Mesembryanthemum aequilaterale, Haw. Misc. Nat. p. 77 ; Benth. Fl. Austral. iii, p. 324 ; F. Muell. Fragm. ix, p. 77 .

All round Australia, and in western South America and California; chiefly on the coast and in salt-marshes. It is closely allied to the South African $M$. acinaciforme, Linn.

40. Mesembryanthemum australe, Sol. in Forst. f. Prod. p. 90 ; Benth. Fl. Austral. iii, p. 324 ; F. Muell. Fragm. ix, p. 77 ; Salm-Dyck, Monogr. § I8, fig. 2; F. Muell. Key Vict. Pl. t. 39 , figs. $a, b$.

Throughout Australia, New Zealand, Chatham and Norfolk Islands; chiefly saline districts. Bentham states (loc. cit.) that it is probably not really distinct from the South African $M$. crassifolium, Linn.

41. Tetragonia expansa, Murr. in Comm. Götting. vi (1783), p. I3, t. 5 ; Benth. Fl. Austral. iii, p. 325 ; F. Muell. Fragm. ix, p. 77 ; Bot. Mag. t. $23^{62}$; Mart. Fl. Bras. xiv, II, t. $7 \mathrm{I}$.

Australia except the north, New Zealand, Norfolk Island, Western Polynesia to Japan and South America ; chiefly in saline districts.

42. Tetragonia implexicoma, Hook. f. Fl. Tasman. i, p. I 48 ; Benth. Fl. Austral. iii, p. 326 ; F. Muell. Pl. Vict. t. I3 ; 
F. Muell. Key Vict. P1. t. 40, figs. $a, b$; Fragm. ix, p. 77 ; x, p. 84 .

Australia generally, Tasmania, and New Zealand; chiefly in saline districts.

43. Sesuvium Portulacastrum, L. Syst. Nat. ed. x, p. $105^{8}$; Benth. Fl. Austral. iii, p. 328 ; F. Muell. Fragm. ix, p. 77 ; Bot. Mag. t. I70I ; Hemsl. Rep. Voy. Chall. Bot. i, 3, p. I55; Mart. Fl. Bras. xiv, II, t. 70.

Generally diffused in tropical and subtropical maritime districts.

\section{UMBELLIFERAE.}

44. Hydrocotyle hirta, R. Br. in Annal. Sci. Phys. vi (1820), p. 64 ; Benth. Fl. Austral. iii, p. 339 ; F. Muell. Fragm. ix, p. 77 ; Mart. Fl. Bras. xi, I, p. 28 I, t. 75, f. 2.

Tasmania and Australia, except the north.

This is one of a group of very closely allied species, or forms of one species, scattered over tropical Asia, Africa, and America.

45. Apium prostratum, Labill. Relat. i, p. 14I ; Vent. Jard. Malm. t. 8I ; Benth. Fl. Austral. iii, p. 372; Labill. Pl. Nov. Holland. i, p. 76, t. 103 ; F. Muell. Fragm. ix, p. 77. Australasia, Polynesia, South Africa, and extratropical South America.

\section{Araliaceae.}

46. Panax cissodendron, C. Moore \& F. Muell. in F. Muell. Fragm. vii, p. 96 ; viii, p. 280 ; ix, p. 77.

Endemic.

Allied to the New South Wales $P$. Murrayi, F. Muell. It is locally known as pine wood, on account of its whiteness.

\section{RUBIACEAE.}

47. Randia stipulosa, C. Moore \& F. Muell. in F. Muell. Fragm. vii, p. 47 ; ix p. 77.

Randia macrophylla, C. Moore, Rep. p. 3, nomen tantum.

Gardenia stipulosa, C. Moore \& F. Muell. loc. cit.

Endemic.

Closely allied to R. Fitzalani, F. Muell.; a native of Queensland. 
48. Psychotria Carronis, F. Muell. Fragm.vii, p. 49; ix, p. 77 . Endemic.

Remarkable among Australasian species for the large size of its fruit.

49. Coprosma Baueri, Endl. Iconogr. Gen. Pl. xi, t. I I I ; F. Muell. Fragm. ix, pp. 69 et 77 ; Kirk, For. Fl. N. Zeal. t. 62.

Coprosma Baueriana, Hook.f. Fl. N. Zeal. i, p. I05; Handb. Fl. N. Zeal. p. II 2.

Coprosma lucida, Forst. Char. Gen. p. I 38 ; Endl. Prodr. Fl. Norf. p. 60.

New Zealand and Norfolk Island.

50. Coprosma lanceolaris, F. Muell. Fragm. ix, p. 70 , et p. 77 .

Endemic.

This species is very similar to C. affinis, Hook. f. (Fl. Ant. i, p. 2 I, t. I 4), a native of the Auckland Islands.

51. Coprosma putida, C. Moore \& F. Muell. Fragm. vii, p. 45; ix, p. 77 ; Moore Rep. p. 2.

Endemic.

This has an exceedingly penetrating odour, in a genus having a very appropriate name. It bears the local name of stinkwood.

\section{Compositae.}

52. Brachycome segmentosa, C. Moore \& F. Muell. in F. Muell. Fragm. viii, p. I44.

Endemic.

In the place cited, Sir F. von Mueller describes this as distinct from $B$. diversifolia, Fisch. et Mey., and it is probably through a slip of the pen that the latter name appears in his list of Lord Howe Island plants.

-Fragm. ix, p. 77.

53. Olearia Ballii, F. Muell. Fragm. viii, p. I43. Aster Ballii, F. Muell. loc. cit. et ix, p. 77.

Endemic.

54. Olearia Mooneyi, F. Muell. Fragm. viii, p. I44. Aster Mooneyi, F. Muell. loc. cit. et ix, p. 77 . Endemic. 
This and the preceding are both shrubby, and this attains several feet in height, but there are no arboreous Compositae in the island.

55. Gnaphalium japonicum, Thunb. Fl. Jap. p. 3 I I ; Benth. F1. Austral. iii, p. 653 ; F. Muell. Fragm. ix, p. 77.

Gnaphalium involucratum, Forst. f. Prod. p. 55 ; Bot. Mag. t. 2582 .

New Zealand, Australia, and Eastern Asia.

56. Gnaphalium luteo-album, L. Sp. Pl. p. 85I ; Benth. Fl. Austral. iii, p. 653 ; Engl. Bot. ed. iii, t. 742 .

Cosmopolitan except the colder regions.

57. Cassinia tenuifolia, Benth. Fl. Austral. iii, p. 585 ; F. Muell. Fragm. ix, p. 77 .

Endemic.

58. Wedelia biflora, DC. in Wight, Contrib. p. I8; Benth. F1. Austral. iii, p. 539 ; F. Muell. Fragm. ix, p. 77.

Wollastonia biflora, DC. Prod. v, p. 546 ; Wight, Ic. t. I Io8. Tropics, except America.

59. Bidens pilosa, L. Sp. P1. p. 832 ; Benth. Fl. Austral. iii, p. 543 ; F. Muell. Fragm. ix, p. 77.

A common weed in almost all warm countries.

60. Erechthites quadridentata, DC. Prod. vi, p. 295 ; Benth. Fl. Austral. iii, p. 660 ; F. Muell. Fragm. ix, p. 77.

Senecio quadridentatus, Labill. Pl. Nov. Holland. ii, p. 48, t. I94.

New Zealand, Tasmania, and Australia except the north:

61. Senecio insularis, Benth. Fl. Austral. iii, p. 666 ; F. Muell. Fragm. ix, p. 77.

Endemic.

Very distinct, and more nearly allied to the New Zealand S. glastifolius, Hook. f., than to any of the Australian species.

XXVI. GoOdeniaceae.

62. Scaevola Koenigii, Vahl, Symb. Bot. iii. p. $3^{6}$; Benth. Fl. Austral. iv, p. 86; F. Muell. Fragm. ix, p. 77 ; Bot. Mag. t. 2732 ; Hemsl. Rep. Voy. Chall. Bot. i, 3, p. I6r. 
Scaevola Lobelia, Auct. P1. non Murr.; Hillebr. Fl. Haw. p. 265 .

Scaevola latevaga, Hance, in Walp. Ann. ii, p. 1054.

Queensland, North Australia, throughout Polynesia, and in tropical Asia.

\section{Campanulaceae.}

63. Lobelia anceps, L. f. Suppl.p. 395 ; Benth. Fl. Austral. iv, p. 128 ; F. Muell. Fragm. ix, p. 77.

Lobelia decumbens, Sims, Bot. Mag. t. 2277.

Australia, except the north, New Zealand, Chatham Island, South Africa, and extratropical South America.

64. Wahlenbergia gracilis, Schrad. Blumenb. p. $3^{8}$, in obs. ; A. DC. Monog. Camp. p. I42 ; Benth. Fl. Austral. iv, p. I37 ; F. Muell. Fragm. ix, p. 77 ; Charsl. Wild Fl. Melb. t. Io.

Campanula gracilis, Forst. f. Prod. p. 15 ; Sm. Exot. Bot. t. 45 .

Throughout Australia, New Zealand, Kermadec Islands, New Caledonia, Tonga Islands, Eastern Asia, and South Africa.

\section{EPACRIDEAE.}

65. Leucopogon Richei, R. Br. Prod. p. 54I ; Benth. Fl. Austral. iv, p. I86; F. Muell. Veg. Chath. Isd. p. 45 ; Bot. Mag. t. 325I.

Styphelia Richei, Labill. Nov. Holl. Pl. Sp. i, p. 44, t. 60 ; F. Muell. Fragm. ix, p. 77 .

Australia, except the north, Chatham Island, but not in New Zealand.

66. Dracophyllum Fitzgeraldi, F. Muell. Fragm. vii, p. 27, t. 62 ; ix, p. 77 ; Wils. Rep. p. 32 .

Endemic.

'The largest tree known of the order Epacridaceae, is met with at an elevation of about $\mathbf{I}, 000$ feet, and at this height on the mountains it is a large tree fifty to sixty feet high, with trunks three to nearly five feet in diameter, but it is much smaller as it approaches the top of the mountains, where it is finally reduced to a shrub or small stunted tree of ten to fifteen feet in height.'-Durf. 
XXIX. MYrsineAE.

67. Myrsine crassifolia, R. Br. Prod. p. 534 ; Benth. F1. Austral. iv, p. 275 ; F. Muell. Fragm. viii, p. 48 ; ix, p. 77.

New South Wales, Queensland, and Norfolk Island.

68. Myrsine platystigma, F. Muell. Fragm. viii, p. 48 ; ix, p. 77 .

Endemic.

69. Aegiceras majus, Gaertn. Fruct. i, p. 216 , t. 46 ; Benth. Fl. Austral. iv, p. 277 ; F. Muell. Fragm. ix, p. 77 ; Wight, Illustr. Ind. P1. t. I46.

Aegiceras fragrans, Kon. ; Moore, Rep. p. 3 .

New South Wales, Queensland, North Australia, tropical Asia, New Guinea, Solomon Islands.

XXX. Sapotaceae.

70. Sideroxylon Howeanum, F. Muell. Cens. Austral. Plants, ed. I, p. 92, 1882.

Achras Howeana, F. Muell. Fragm. ix, pp. 72 et 77 .

Achras costata, Moore, Rep. p. 2, non Endl.

Endemic.

This is referred to in Bentham's Flora Australiensis, iv, p. 82, under Achras australis, $\mathrm{R}$. Br.

XXXI. Styraceae.

71. Symplocos Stawelli, F. Muell. Fragm. v, p. 60; ix, p. 77 ; Benth. Fl. Austral. iv, p. 292 (sub spicata).

New South Wales and Queensland.

\section{Oleaceae.}

72. Jasminum didymum, Forst. f. Prod. p. 3 ; Benth. Fl. Austral. iv, p. 294 ; Bot. Mag. t. 6349 ; F. Muell. Fragm. ix, p. 77 .

New Caledonia, Fiji, Tonga and Society Islands, and Northern Australia to Java. 
73. Jasminum simplicifolium, Forst. f. Prod. p. 3 ; Benth. Fl. Austral. iv, p. 296; Bot. Mag. t. 980; F. Muell. Fragm. ix, p. 77 .

Fasminum gracile, Andr. Bot. Rep. t. 127 ; Bot. Reg. t. 606 ; Endl. Prodr. Fl. Norf. p. 55.

Norfolk Island, New Hebrides, Fiji, and Tonga Islands; also the eastern coast of Australia and Norfolk Island.

74. Notelaea quadristaminea, Hemsl.

Chionanthus quadristaminea, F. Muell. Fragm. viii, p. 4I ; ix, p. 77 .

Mayepea quadristaminea, F. Muell. Fragm. x, p. 89 ; Census Austral. Pl. ed. II, p. 156.

Endemic.

75. Olea paniculata, R. Br. Prod. p. 523 ; Benth. Fl. Austral. iv, p. 297 ; Moore, Rep. p. 3 ; F. Muell. Fragm. ix, p. 77 .

New South Wales, Queensland, and New Caledonia.

XXXIII. Apocynaceae.

76. Alyxia Lindii, F. Muell. Fragm. viii, p. 46; ix, p. 77. Endemic.

77. Alyxia ruscifolia, R. Br. Prod. p. 470 ; Benth. Fl. Austral. iv, p. 308 ; Bot. Mag. t. 33 I2: F. Muell. Census Austral. Pl. ed. II, p. I56 ; Fragm. ix, p. 77.

New South Wales and Queensland, and also Polynesia, according to Mueller.

78. Alyxia squamulosa, C. Moore \& F. Muell. in F. Muell. Fragm. viii, p. 47 ; ix, p. 77.

Endemic.

79. Ochrosia elliptica, Labill. Sert. Austro-Caled. p. 25, t. 30 ; Benth. Fl. Austral. iv, p. 3Io; F. Muell. Census Austral. P1. ed. II, p. I56 ; F. Muell. Fragm. ix, p. 77.

Queensland, New Caledonia, Fiji and other islands of the South Pacific. Also in Asia, according to Mueller. 
80. Lyonsia reticulata, F. Muell. Rep. Burdek. Exped. p. I6; Benth. Fl. Austral. iv, p. 321 ; F. Muell. Fragm. ix, p. 77 .

New South Wales and Queensland.

\section{Asclepiadaceae.}

81. Vincetoxicum carnosum, Benth. Fl. Austral. iv, p. 33I. Oxystelma carnosum, R. Br. Prod. Fl. Nov. Holl. p. 462.

New South Wales, Queensland, and North Australia.

82. Tylophora enervis, F. Muell. Fragm. ix, pp. 70 et 77 .

Endemic.

This is very similar to the Norfolk Island T. biglandulosa, F. Muell., syn. Hybanthera biglandulosa, Endl.

83. Marsdenia rostrata, R. Br. in Mem. Wern. Soc. i (1 809), p. 3I ; Benth. Fl. Austral. iv, p. 339 ; F. Muell. Fragm. ix, p. 77 .

Victoria, New South Wales, and Queensland.

It seems doubtful whether there are two species of this genus in the island, because the flowers of this species, as circumscribed by Bentham, vary considerably in size; and I have seen no authenticated specimen of the following.

84. Niarsdenia tubulosa, F. Muell. Fragm. ix, pp. 7 I et 77 .

Endemic.

Mueller (loc. cit.) records both this and $M$. rostrata from the island, but all the specimens in the Kew Herbarium are of one species, having, as Bentham states, larger flowers than ordinary rostrata, though he refers them to that species.

\section{LOGANIACEAE.}

85. Geniostoma petiolosum, C. Moore \& F. Muell. in F. Muell. Fragm. vii, p. 28 ; ix, p. 77.

Endemic. 


\section{Solanaceae.}

86. Solanum aviculare, Forst. f. Prod. p. 18 ; Benth. Fl. Austral. iv, p. 447 ; F. Muell. Fragm. ix, p. 78.

Solanum laciniatum, Ait. Hort. Kew. ed. I, i, p. 247 ; Bot. Mag. t. 349.

New Zealand, Tasmania, South and East Australia, and Norfolk Island.

87. Solanum Bauerianum, Endl. Prod. Fl. Norf. p. 54; F. Muell. Fragm. ix, p. 78 .

Norfolk Island.

\section{Convolvulaceae.}

88. Ipomoea biloba, Forsk. Fl. Aegypt-Arab. p. 44.

Ipomoea Pes-caprae, Roth. Nov. Sp. Pl. p. I09; Benth. Fl. Austral. iv, p. 4I9; Hemsl. Rep. Voy. Chall. Bot. i, I, p. 5I ; 2, p. $80 ; 3$, p. 169 ; F. Muell. Fragm. ix, p. 78. Ipomoea maritima, R. Br. Prod. p. 486 ; Bot. Reg. t. 3 I9.

Almost cosmopolitan on sandy seashores in tropical and subtropical countries, including remote islands.

89. Ipomoea bona-nox, L. Sp. Pl. ed. II, p. 228; F. Muell. Fragm. ix, pp. 74 et 78 .

Now very widely spread in warm countries, but supposed to be indigenous only in tropical America.

90. Ipomoea grandiflora, Lam. Tabl. Encyc. i, p. 467; Andr. Bot. Rep. vi, t. 403 .

Ipomoea longiflora, R. Br. Prod. p. 484; Benth. Fl. Austral. iv, p. 4I 8 .

Queensland, North Australia, Polynesia, tropical Asia and Africa.

This is not in Mueller's list, but there is a specimen in the Kew Herbarium received from him.

91. Ipomoea palmata, Forsk. Fl. Aegypt-Arab. p. 43 ; Benth. Fl. Austral. iv, p. 4I 5 ; F. Muell. Fragm. ix, p. 78. Ipomoea pendula, R. Br. Prod. p. 486 ; Andr. Bot. Rep. t. 61 3 ; Bot. Reg. t. 632 .

Tropics of both hemispheres. 
92. Calystegia marginata, R. Br. Prod. p. 484 ; Hook. f. Fl. N. Zeal. t. 48.

Convolvulus marginatus, Spreng. Syst. i, p. 603 ;-Benth. Fl. Austral. iv, p. 430 ; F. Muell. Fragm. ix, p. 78 ; x, p. II 3 .

Calystegia affinis, Endl. Prodr. Fl. Ins. Norf. p. 5I, fide F. Muell. loc. cit.

New Zealand, South-eastern Australia, and Norfolk Island.

93. Calystegia Soldanella, R. Br. Prod. p. 483 .

Convolvulus Soldanella, L. Sp. Pl. p. I59; Benth. Fl. Austral. iv, p. 43I ; F. Muell. Fragm. x, p. I13; Engl. Bot. ed. III, t. 925 .

Convolvulus sepium, L. var. Soldanella, F. Muell. Fragm. ix, p. 78 .

Cosmopolitan on seashores in temperate and subtropical countries.

\section{GESNERACEAE.}

94. Negria rhabdothamnoides, F. Muell. Fragm. vii, p. I $5^{2}$; viii, p. 28 I ; ix, p. 78 ; Baill. in Assoc. Franç. pour l'Avanc. Sc. 1878 , p. 646 , t. 9 ; C. B. Clarke in DC. Monogr. Phanerog. v, pars i, p. I75.

Endemic.

A small tree attaining the height of eighteen feet, erroneously given as metres by Mr. Clarke.

The allied monotypic Rhabdothamnus is endemic in New Zealand. Fieldia is another monotypic genus of this order. This is restricted to Victoria and New South Wales. Besides these only two species of other genera of this order have been found in Australia-Queensland. The genus Cyrtandra, of which there are nearly a hundred species scattered over Polynesia, is not known to be represented in Australia.

\section{BIGNONIACEAE.}

95. Tecoma austro-caledonica, Bur. in Bull. Soc. Bot. Fr. ix (1862), p. I63.

Pandorea austro-caledonica, Seem. in Gard. Chron. I870, p. 1085 .

Tecoma australis, Moore Rep. p. 2, non R. Br.

New Caledonia.

Sir F. von Mueller (Fragm. ix, p. 77) also records $T$. australis, $\mathrm{R}$. Br., from the island. 
Xl. Acanthaceae.

96. Eranthemum variabile, R. Br. Prod. p. 477 ; Benth. Fl. Austral. iv, p. 555 ; F. Muell. Fragm. ix, p. 78.

New South Wales, Queensland, and New Caledonia.

XLI. MyoporaceAe.

97. Myoporum insulare, R. Br. Prodr. p. 5I6; Benth. Fl. Austral. v, p. 5 (sub $M$. serrato); F. Muell. Fragm. vi. p. 149 ; vii, p. IIO; ix, p. 78 ; F. Muell. Myop. P1. Frontisp. et t. 72 ; Gard. Chron. n.s. xxv (1886), pp. 492-3, fig. 92.

Myoporum acuminatum, Moore, Rep. p. 2, non R. Br.

Tasmania, West Australia, South Australia, Victoria, and New South Wales.

This and the Sandwich Islands species, M. sandwicense, A. Gr., are the only arboreous ones. The present one attains a height of forty feet, with a trunk of considerable thickness. A representation of it forms the frontispiece to Mueller's Lithograms of Myoporineous Plants.

\section{VERBENACEAE.}

98. Avicennia officinalis, L. Sp. Pl. p. IIO; Benth. Fl. Austral. v, p. 69 ; Kirk, For. Fl. N. Zeal. t. I30; F. Muell. Fragm. ix, p. 78 .

Avicennia tomentosa, Jacq. Enum. Pl. Carib. p. 2.5; Wall. Pl. As. Rar. t. $27 \mathrm{I}$; Wight, Ic. t. 148 I.

Tropical and subtropical seashores throughout the world, though rare in Polynesia. It reaches New Zealand in the south and the Bermudas in the north.

\section{LABIATAE.}

99. Westringia rosmariniformis, Sm. in Vet. Acad. Handl. Stockh. (I797) p. I 7 I Benth. Fl. Austral. v, p. I 28 ; F. Muell. Fragm. ix, p. 78 .

Westringia rosmarinacea, Andr. Bot. Rep. t. 214.

Tasmania, Victoria, New South Wales, and Queensland.

The genus Westringia is otherwise restricted to Australia and Tasmania, inhabiting all except the hotter parts. 


\section{XliV. Plantagineae.}

100. Plantago varia, R. Br. Prod. p. 424 ; Benth. Fl. Austral. v, p. I39; Turner, Forage Pl. Austral. p. 45; F. Muell. Fragm. ix, p. 78 .

Throughout Australia.

An exceedingly variable species, of which nearly a dozen forms have been described as species.

\section{Nyctaginaceae.}

101. Boerhaavia diffusa, L. Fl. Zeyl. p. 4 ; Benth. Fl. Austral. v. p. 277 ; F. Muell. Key Vict. Pl. f. 44 ; F. Muell. Fragm. ix, p. 77 .

Boerhaavia procumbens, Roxb. Fl. Ind. i, p. I46 ; Wight, Ic. t. 874 .

Australia, Polynesia, and tropical and subtropical Asia and Africa.

102. Pisonia umbellifera, Seem. in Bonpl. x, p. 154 ; Fl. Vict. p. I95; Hillebr. Fl. Haw. p. 368 ; Drake, Fl. Polyn. Franç. p. I 57 .

Pisonia Brunoniana, Endl. Prodr. Fl. Norf. p. 43; Benth. Fl. Austral. v, p. 280 ; F. Muell. Fragm. ix, p. 77 ; Kirk, For. Fl. N. Zeal. t. I 40.

Pisonia excelsa, Blume, Bijdr. p. 735; Hook. f. Fl. Brit. Ind. iv, p. 7II.

New Zealand, Norfolk Island, New South Wales, and Queensland, throughout Polynesia, Malaya, and the Andaman Islands.

Authors by no means agree as to the limits of this species and the name it should bear. The synonyms are very numerous.

XlVi. Chenopodiaceae.

103. Rhagodia Billardierii, R. Br. Prod. p. 408 ; Benth. Fl. Austral. v, p. I52; F. Muell. Ic. Salsol. t. 2I ; F. Muell. Fragm. ix, p. 77 .

Chenopodium baccatum, Labill. P1. Nov. Holl. i, p. 71, t. 96. Throughout Australia, in salt-marshes and on the coast.

104. Atriplex cinereum, Poir. Encyc. Suppl. i, p. 47I ; Benth. Fl. Austral. v, p. I7I ; Turner, Forage Pl. Austral. 
p. 58 ; F. Muell. Ic. Salsol. t. I 2 ; Hook. f. Handb. Fl. N. Zeal. p. 232 ; F. Muell. Fragm. ix, p. 77.

New Zealand, Tasmania, and Australia except the north; inhabiting the coast and salt-marshes.

\section{AmarantaceaE.}

105. Achyranthes aspera, L. Sp. P1. p. 204 ; Benth. Fl. Austral. v, p. 246 ; Wight, Ic. t. 1777 ; F. Muell. Fragm. ix, p. 77 .

Generally spread in warm countries.

\section{Polygonaceae.}

106. Muehlenbeckia axillaris, Walp. Ann. i, p. 552; Benth. Fl. Austral. v, p. 275 ; F. Muell. Fragm. ix, p. 77.

New Zealand, Tasmania, Victoria, and New South Wales.

\section{Piperaceae.}

107. Piper excelsum, Forst. f. Prod. p. 5 ; Benth. Fl. Austral. vi, p. 204; Hook. f. Handb. Fl. N. Zeal. p. 254; F. Muell. Fragm. ix, p. 77.

New Zealand, Kermadec, Chatham, and Norfolk Islands, and Southern Polynesia.

108. Peperomia reflexa, A. Dietr. Sp. P1. i, p. I80; Benth. F1. Austral. vi, p. 207 ; Wight, Ic. t. 1923; F. Muell. Fragm. ix, p. 77 .

Common in most warm countries.

109. Peperomia Urvilleana, A. Rich. in Urville, Voy. Bot. p. 356 ; F. Muell. Fragm. ix, p. 77 ; Hook. f. Handb. Fl. N. Zeal. p. 254 .

New Zealand, Norfolk Island, and the Kermadecs.

Peperomia leptostachya, Hook. et Arn., is included in Prof. Tate's list, probably by mistake.

\section{LAURINEAE.}

110. Cryptocarya triplinervis, R. Br. Prod. p. 402 ; Benth. Fl. Austral. v, p. 297 ; F. Muell. Fragm. ix, p. 77.

Tetranthera, sp. Moore, Rep. p. 2.

New South Wales and Queensland. 


\section{ThymelaEACEAE.}

111. Pimelea longifolia, Banks et Sol. ex Wikstr. in Vet. Akad. Handl. Stockh. (1818) p. 280 ; Benth. Fl. A ustral. vi, p. 7 ; F. Muell. Fragm. ix, p. 77 ; Hook. f. Handb. Fl. N. Zeal. p. 242.

Pimelea congesta, F. Muell. Fragm. viii, p. 9.

New Zealand, but confined to the main islands.

\section{LiI. Santalaceae.}

112. Exocarpus homaloclada, F. Muell. Fragm. viii, p. 9; ix, p. 77 ; Benth. Fl. Austral. vi, p. 230.

Endemic.

The range of this singular genus is from New Zealand, Norfolk Island, and New Caledonia, throughout Australia and the Malay Archipelago to the Philippines, with an outlier in the Sandwich Islands. The supposed Madagascar species proves to be a member of the Leguminosae-Phylloxylon, Baill.

\section{LORANTHACEAE.}

113. Viscum articulatum, Burm. f. Fl. Ind. p. 31 I ; Benth. Fl. Austral. iii, p. 396 ; F. Muell. Fragm. ix, p. 77.

Viscum moniliforme, Blume, Bijdr. p. 667 ; Wight, Ic. tt. IOI 8, I019.

Viscum opuntioides, Moore, Rep. p. 2, non Linn.

New South Wales, Queensland, Polynesia, and tropical Asia.

\section{LiV. Euphorbiaceae.}

114. Euphorbia Sparmanni, Boiss. Cent. Euphorb. p. 5 ; Benth. Fl. Austral. vi, p. 46 ; Hemsl. in Journ. Linn. Soc. xxx, p. I9I ; F. Muell. Fragm. ix, p. 77.

New South Wales, Tonga, Elizabeth, and Pitcairn Islands.

115. Hemicyclia australasica, Muell. Arg. in DC. Prod. xv, II, p. 487 ; Benth. Fl. Austral. vi, p. I 8

Hemicyclia sepiaria, F. Muell. Fragm. ix, p. 77.

New South Wales and Queensland. 
116. Baloghia lucida, Endl. Prod. Fl. Norf. p. 84 ; Benth. Fl. Austral. vi, p. I48; Endl. Iconogr. tt. I22, I23; F. Muell. Census Austral. Pl. ed. II, p. 37 ; F. Muell. Fragm. ix, p. 77. New Caledonia, Norfolk Island, New South Wales, and Queensland.

117. Homalanthus Leschenaultianus, A. Juss. Tent. Euphorb. p. 50, t. 16.

Carumbium populifolium, Reinw. in Blume, Cat. Hort. Buitenz. p. 105; Benth. Fl. Austral. vi, p. I50; F. Muell. Fragm. ix, p. 77 .

Victoria, New South Wales, Queensland, Malaya, and Polynesia.

\section{URTICACEAE.}

118. Celtis amblyophylla, F. Muell. Fragm. ix, pp. 76 et 77; Benth. Fl. Austral. vi, p. I57 (sub C. paniculata).

Endemic.

This is the cotton-wood of the settlers.

119. Malaisia tortuosa, Blanco, Fl. Filip. ed. I, p. 789 ; Benth. Fl. Austral. vi, p. I 80 ; Vidal. Fl. For. Filip. t. 86,f. b ; F. Muell. Fragm. ix, p. 77 .

Caturus scandens, Lour. Fl. Cochinch. p. 61 2.

New South Wales, Queensland, North Australia, Western Polynesia, and Malaya.

120. Ficus columnaris, F. Muell. \& C. Moore, in Proc. Acclim. Soc. Vict. iii (1874), p. 7I ; F. Muell. Fragm. vii. t. 6 I ; ix, p. 77 ; Wils. Rep. p. 32 .

Ficus rubiginosa, Desf.; Benth. Fl. Austral. vi, p. I68, pro parte.

Endemic.

Mr. Duff states that the fine old banyan trees are rapidly dying off, and he thinks there is a danger of the species becoming extinct in the island.

121. Elatostema reticulatum, Wedd. in Ann. Sci. Nat. ser. IV, i, p. I88; Benth. Fl. Austral. vi, p. I83; F. Muell. Fragm. ix, p. 77 .

New South Wales and Queensland. 
122. Boehmeria calophleba, C. Moore \& F. Muell. in F. Muell. Fragm. viii, p. II ; ix, p. 77; Benth. Fl. Austral. vi, p. I84.

Endemic.

Allied to the Norfolk Island $B$. australis, Endl.

123. Parietaria debilis, Forst. f. Prod. p. 73 ; Benth. Fl. Austral. vi, p. I88; F. Muell. Fragm. ix, p. 77.

Widely spread in temperate and tropical regions of both hemispheres.

LVI. ORCHIDEAE.

124. Dendrobium gracilicaule, F. Muell. Fragm. i, p. I79; ix, p. 78 ; Benth. Fl. Austral. vi, p. 281 ; Bot. Mag. t. 7042.

Dendrobium elongatum, A. Cunn. in Bot. Reg. I839, Misc. p. 33, non Lindl. Gen. et Sp. Orch. p. 77.

New South Wales and Queensland.

125. Dendrobium Moorei, F. Muell. Fragm. vii, p. 26 ; ix, p. 78 ; Benth. Fl. Austral. vi, p. 28I ; Fitzger. Austr. Orch. i, pt. 6.

Endemic.

126. Bulbophyllum exiguum, F. Muell. Fragm. ii, p. 72; ix, p. 78 ; Benth. Fl. Austral. vi, p. 288 ; Fitzger. Austr. Orch. ii, pt. 5 .

New South Wales and Queensland.

Allied to $B$. pygmaeum, Lindl., an endemic, and the only New Zealand species.

127. Cleisostoma erectum, Fitzg. Orch. Austral. i, pt. iv.

Sarcochilus erectus, F. Muell. Census, ed. I, p. I I I ; ed. II, p. 187 .

Endemic.

128. Microtis porrifolia, Spreng. Syst. iii, p. 7 I3; Hook. f. Handb. Fl. N. Zeal. p. 266 ; Benth. Fl. Austral. vi, p. 347 ; Fitzger. Austral. Orch. v, pt. 2; F. Muell. Fragm. ix, p. 78 ; $\mathrm{x}$, p. 65 .

Tasmania, West Australia, South Australia, Victoria, New South Wales and Queensland, New Zealand and Polynesia. 


\section{AMARYLLIDACEAE.}

129. Crinum pedunculatum, R. Br. Prod. p. 297 ; Benth. Fl. Austral. vi, p. 455 ; F. Muell. Fragm. ix, p. 78 ; Bull. Soc. Tosc. 1886, p. 267 ; Baker, Amaryl. p. 77 ; Bot. Reg. t. 52. Crinum taitense, Redouté, Lil. t. 408.

South Australia, New South Wales, and Queensland, New Guinea, New Caledonia, and Fiji.

\section{IRIDEAE.}

130. Moraea Robinsoniana, C. Moore \& F. Muell. in F. Muell. Fragm. vii, p. I53; Benth. Fl. Austral. vi, p. 409; Bot. Mag. t. 7212.

Iris Robinsoniana, F. Muell. Fragm. vii, p. I53, tt. 63-64; ix, p. 78 .

This is apparently endemic, but Mueller (Fragm. viii, p. 28I) states that ' $\mathrm{Cl}$. Hill hanc plantam e montibus Bellenden Kerii indicat, unde autem nondum exemplaria habeo.'

LiX. Liliaceae.

131. Smilax australis, R. Br. Prod. p. 293; Benth. Fl. Austral. vii, p. 7 ; F. Muell. Key Vict. Pl. t. II 7 ; F. Muell. Fragm. ix, p. 78 .

Smilax elliptica et latifolia, R. Br. Prod. p. 293.

Eastern Australia from Victoria northwards to the islands of the Gulf of Carpentaria.

A. de Candolle (Monogr. Phaner. i, p. 64) records the Polynesian Smilax purpurata, Forst., from Howe Island.

132. Geitonoplesium cymosum, A. Cunn. in Bot. Mag. t. $3^{1} 3^{1} ;$ Benth. Fl. Austral. vii, p. I9.

Victoria, New South Wales, and Queensland, Norfolk Island, South Pacific Islands, and Borneo.

A monotype.

133. Dianella caerulea, Sims, Bot. Mag. t. $5 \circ 5$; Benth. Fl. Austral. vii, p. I6.

New South Wales, Queensland, and North Australia.

There is no specimen of this in the Kew Herbarium. 
LX. Commelinaceae.

134. Commelina cyanea, R. Br. Prod. p. 269; Benth. Fl. Austral. vii, p. 84 .

C. communis, Muell. Fragm. viii, p. 59 ; ix, p. 78 , non Linn.; Clarke, Comm. \& Cyrt. Beng. t. I, et in DC. Monogr. Phanerog. iii, p. 147.

Eastern Australia and New Caledonia.

LXI. Flagellariaceae.

135. Flagellaria indica, L. Sp. Pl. p. 333; Benth. Fl. Austral. vii, p. Io; Red. Lil. v, t. 257 ; Hemsl. Rep. Voy. Chall. Bot. i, pt. 3, p. 202 ; F. Muell. Fragm. ix, p. 78.

Australasia, Western Polynesia, tropical Asia and Africa, chiefly on the seashores.

The specimen from the island in the Kew Herbarium, collected by Milne, consists of leaves only, remarkable for their length, being about eighteen inches long.

The only other species of the genus, $F$. gigantea, Hook. $f$. (Hooker's Ic. Pl. t. I 429), inhabits Samoa and Fiji.

\section{Juncaceae.}

136. Juncus maritimus, Lam. Encyc. iii, p. 264; Benth. Fl. Austral. vii, p. I30; Engl. Bot. ed. III, t. I 559 ; Buchen. Abh. Nat. Ver. Bremen, iv, t. 4; F. Muell. Fragm. ix, p. 78.

Temperate and subtropical regions of the eastern hemisphere.

137. Luzula longiflora, Benth. Fl. Austral. vii, p. I23; F. Muell. Census Austral. Pl. ed. II, p. 206.

Luzula campestris, F. Muell. Fragm. ix, p. 78, non DC.

Endemic.

\section{PALMAE.}

138. Hedyscepe Canterburyana, Wendl. et Drude in Linnaea, xxxix (1875), pp. I78, I89, et 203, t. I, fig. 4 .

Kentia Canterburyana, F. Muell. Fragm. vii, p. IOI, t. 62; viii, p. 234 ; ix, p. 78 ; Benth. Fl. Austral. vii, p. 138 ; Duff in Wils. Rep. p. $3^{\text {I. }}$

Endemic.

The Umbrella Palm of the settlers. 
139. Clinostigma Mooreanum, F. Muell. Fragm. viii, p. 235 ; Benth. Fl. Austral. vii, p. I 39 ; Wendl. et Drude in Linnaea, xxxix (1875), pp. I 85 et 218 , t. 2, fig. 5 .

Clinostigma Moorei, F. Muell. Fragm. ix, p. 78 ; Duff in Wils. Rep. p. 3I.

Kentia Mooreana, F. Muell. Fragm. vii, p. IOI ; viii, p. 234.

Endemic.

A dwarf Palm not more than six feet high, restricted to the summits of the mountains.

140. Howea Belmoreana, Becc. Malesia, i (1877), p. 66.

Kentia Belmoreana, F. Muell. Fragm. vii, p. 99, t. 6I ; viii, p. 234; ix, p. 78 ; Benth. Fl. Austral. vii, p. I37; Duff in Wils. Rep. p. 30.

Grisebachia Belmoreana, Wendl. et Drude in Linnaea, xxxix (I 875 ), p. 202, t. 4, fig. I.

Endemic.

The Curly Palm of the settlers.

141. Howea Forsteriana, Becc. Malesia, i (1877), p. 66.

Kentia Forsteriana, F. Muell. ex H. Wendl. in Kerch. Palm. p. 248 ; F. Muell. Fragm. vii, t. 61 ; ix, p. 78 ; Duff in Wils. Rep. p. 30.

Grisebachia Forsteriana, Wendl. et Drude in Linnaea, xxxix (1875), p. 203, t. 4, fig. 2.

Endemic.

The Thatch Palm of the settlers.

Mr. Duff gives the following particulars of the Palms, which have been confused in the young state:-

'Both palms [Howea Forsteriana and H. Belmoreana] flower exactly alike, i.e. they produce their flower-spikes generally from the axils of the lowest row of leaves, but occasionally young undeveloped flower-spikes spring from the axils of the leaves above them, and their ripe seeds [fruits] are always emitted from immediately under the leaves. The seeds [fruits] of the curly palm are oval and a greenish-yellow colour when ripe, whilst those of the thatch palm taper to a point at both ends and are dark crimson when mature.'

' The curly palm is the most abundant and wide-spread species, as it extends from the beach to an elevation of about $\mathbf{I}, 200$ feet on the 
sides of Mounts Gower and Lidgbird, whilst the thatch palm is confined chiefly to the beach, not being found farther up the mountains than from 300 to 400 feet.'

'The fronds and pinnae of the curly palm are recurved at the apex, and the pinnae are nearly erect at the base, the thatch palm having less recurved darker green fronds and broader, pendulous pinnae, which distinctions are observable even in the small seedling plants.'

' The chief specific distinctions, however, between these two palms are as follows:- The curly palm bears its flower-spikes singly, which average 5 to 6 feet in length, and those of the thatch palm consist of five spikes in a row, united together at the base, of an average length of 3 to 4 feet.'

\section{PANDANACEAE.}

142. Pandanus Forsteri, C. Moore \& F. Muell. in F. Muell. Fragm. viii, p. 220 ; ix, p. 78 ; Benth. Fl. Austral. vii, p. I49; Duff in Wils. Rep. p. 32 .

Endemic.

143. Pandanus (species imperfecte cognita), Moore, Rep. p. 2; Duff in Wils. Rep. p. 29.

Endemic.

'The mountain Pandanus is evidently another undescribed plant, differing from Pandanus Forsteriana in having smaller and more numerous branches; shorter, more undulating, and narrower leaves ; cones 6 to 8 inches long, or less than half the size of those of $P$. Forsteriana; height, 20 to 30 feet, with a diameter across the branches of 20 feet; the stems are about 6 inches in diameter, and aerial roots are produced on the branches, a peculiarity rarely seen in Pandanus Forsteriana.'-Duff.

\section{A. NATADACEAE.}

143 A. Halophila ovata, Gaud. in Freyc. Voy., Bot. t. 40, f. I ; F. Muell. Fragm. viii, p. 219.

Halophila ovalis, Hook, f. Fl. Tasm. ii, p. 45 ; Benth. F1. Austral. vii, p. 182 .

Coasts of Tasmania, Victoria, and New South Wales to North Australia; also in the Pacific and Indian Oceans. 


\section{Cyperaceae 1 .}

144. Cyperus haematodes, Endl. Prodr. Fl. Norf. p. 22; Benth. Fl. Austral. vii, p. 285 ; F. Muell. Census Austral. Pl. ed. II, p 2 III.

Cyperus congestus, forma gigantea, F. Muell. Fragm. viii, p. 269.

Cyperus congestus, F. Muell. Fragm. ix, p. 78 non Vahl.

Norfolk Island and Queensland. There is also a specimen in the Kew Herbarium labelled 'Nouvelle Hollande, Verreaux.'

144 A. Cladium insulare, Benth. Fl. Austral. vii, p. 123.

Gahnia insularis, F. Muell. Census Austral. Pl. ed. II, p. 216. Endemic.

145. Scirpus nodosus, Rottb. Desc. et Ic. Pl. Nov. p. $5^{2}$, t. 8 , f. 3 ; Progr. p. 24; Benth. Fl. Austral. vii, p. 33I; Hemsl. Rep. Voy. Chall. Bot. i, 2, p. 87 ; F. Muell. Fragm. ix, p. 78.

Isolepis nodosa, R. Br. Prod. p. $22 \mathrm{I}$; Rich. Bot. Voy. Astrol. N. Zél. t. 18.

South temperate and subtropical regions, generally, including the remote islands of St. Helena, St. Paul, and Amsterdam.

146. Gahnia xanthocarpa, Hook. f. Handb. New Zeal. Fl. p. 306 ; Benth. Fl. Austral. vii, p. 418 .

Cladium xanthocarpum, F. Muell. Fragm. ix, p. I3, et p. 78 . Lampocarya, sp. C. Moore in Trans. Roy. Soc. N. S. Wales, v, p. 32 .

New Zealand, in the northern island only.

147. Uncinia filiformis, Colenso; Hook. f. Fl. N. Zeal. i, p. 286 ; Handb. Fl. N. Zeal. p. 310.

Uncinia debilior, F. Muell. Fragm. viii, p. I5I ; ix, p. $7^{8}$; Benth. Fl. Austral. vii, p. 435 .

New Zealand.

The Howe Island plant is reduced to U. filiformis, Boott, on the authority of Mr. C. B. Clarke.

148. Carex breviculmis, R. Br. Prod. p. 242 ; Benth. Fl.

1 I am indebted to Mr. C. B. Clarke for kindly verifying the nomenclature of the members of this order.-W. B. H. 
Austral. vii, p. 445 ; Hook. f. Fl. N. Zeal. t. 63 ; F. Muell. Fragm. ix, p. 78.

New Zealand, Tasmania, Australia except the west, and Malaya to the Himalayas.

149. Carex gracilis, R. Br. Prod. p. 242 ; Benth. Fl. Austral. vii, p. 442 ; Boott. Ill. Car. i, p. 59, tt. I54-I 55 ; F. Muell. Fragm. ix, p. 78 .

Queensland and New South Wales.

LXVI. Gramineae.

150. Panicum sanguinale, L. Sp. Pl. p. 57; Benth. Fl. Austral. vii, p. 469 ; Trin. Spec. Gram. t. 93; Agric. Gaz. N. S. Wales, ii, t. 21.

Now generally dispersed in warm countries, but commonly as a weed.

151. Oplismenus compositus, Beauv. Agrost. p. 54 ; Benth. Fl. Austral. vii, p. 49 I Agric. Gaz. N. S. Wales, ii, t. 4I.

Panicum compositum, L. Sp. P1. p. 57 ; Trin. Spec. Gram. ii, tt. 187-188, 190; F. Muell. Fragm. viii, p. 199; ix, p. 78.

Generally dispersed in warm countries.

This includes $O$. setarius, Roem. et Schult, $O$. undulatifolius, Beauv., and a host of other synonyms.

152. Phragmites communis, Trin.; Benth. Fl. Austral. vii, p. 636 ; Hook. f. Handb. N. Zeal. Fl. p. 746.

Of world-wide range.

153. Spinifex hirsutus, Labill. Nov. Holl. Pl. ii, p. 8I, tt. 230-3I; Benth. Fl. Austral. vii, p. 503 ; F. Muell. Fragm. ix, p. 78 ; Buchan. Man. Gr. N. Zeal. tt. 8-9; Agric. Gaz. N. S. Wales, v, I 894 , p. 835 .

S. sericeus, R. Br. Prod. p. 198.

New Zealand, New Caledonia, Australia, and Polynesia.

154. Stipa micrantha, Cav. Ic. et Descr. Pl. v, p. 42, t. 467 ; Benth. Fl. Austral. vii, p. 566 ; F. Muell. Fragm. ix, p. 78.

New Zealand and Australia, except the north.

155. Sporobolus indicus, R. Br. Prod. p. I70; Benth. Fl. Austral. vii, p. 622 ; Bail. Gr. Queensl. i; Agric. Gaz. N. S. Wales, ii, t. 29 ; v, p. $3^{89}$.

S. elongatus, R. Br. Prod. p. I70; F. Muell. Fragm. ix, p. 78 . 
Vilfa tenacissima, Trin. Spec. Gram. t. 6o; Buchan. Man. Gr. N. Zeal. t. I 8.

Generally dispersed in warm countries, and extending to some temperate regions, including New Zealand.

156. Deyeuxia Forsteri, Kunth, Rév Gram. i, p. 77 ; Benth. Fl. Austral. vii, p. 579 .

Agrostis Solandri, F. Muell. Veg. Chat. Isl. p. 60.

Agrostis aemula, R. Br. Prod. p. I72; Buchan. Man. Gr.

N. Zeal. t. 2 I.

New Zealand, Tasmania, and Australia except the north.

157. Dichelachne crinita, Hook. f. Fl. New Zeal. i, p. 293 ; Benth. Fl. Austral. vii, p. 574; Bail. Gr. Queensl. i ; Buchan. Man. Gr. N. Zeal. t. 15 .

Anthoxanthum crinitum, L. f. Suppl. p. 90 ; Labill. P1. Nov. Holl. ii, p. II 5 , t. 263.

New Zealand, Tasmania, and Australia except the north.

158. Cynodon Dactylon, Pers. Syn. Pl. i, p. 85 ; Benth. Fl. Austral. vii, p. 609 ; Reichb. Ic. Fl. Germ. t. 26 ; Agric. Gaz. N. S. Wales, ii, I89 I, t. 24 ; Mart. Fl. Bras. ii, III, t. 2 I, f. 3 ; F. Muell. Fragm. ix, p. 78 .

Cosmopolitan in warm countries, and extending to some temperate regions. Often cultivated under the name of Bermuda grass.

159. Chloris Pumilio, R. Br. Prod. p. 186 ; Benth. Fl. Austral. vii, p. 6 I I ; Bail. Gr. Queensl. i; C. Moore, Rep. p. 4.

There is no specimen of this very distinct grass in the Kew Herbarium from the island, nor is it in Mueller's list, and it is included on the authority of Moore's list. It is a native of Queensland and North Australia.

160. Poa caespitosa, Forst. f. Fl. Ins. Austral. Prod. p. 89 ; Benth. Fl. Austral. vii, p. 65I ; F. Muell. Fragm. ix, p. 78 ; Spreng. in Mem. Acad. Petersb. ii (1807-8), p. 302, t. 8 ; Agric. Gaz. N. S. Wales, iv, p. 524.

Poa australis, R. Br. Prod. p. I 79; Buchan. Man. Gr. N. Zeal. t. 47 .

New Zealand, Tasmania, and Australia except the north.

161. Agropyrum scabrum, Beauv. Agrost. p. 102; Benth. Fl. Austral. vii, p. 665 ; Agric. Gaz. N. S. Wales, ii, t. 16. 
Triticum scabrum, R. Br. Prod. p. I78.

Festuca Billardierii, Steud. Syn. P1. Gram. p. 304 ; F. Muell. Fragm. ix, p. 78 .

Festuca scabra, Labill. Pl. Nov. Holl. i, p. 22, t. 26.

New Zealand, Norfolk Island, Tasmania, and Australia except the north.

\section{LYCOPODIACEAE.}

162. Iycopodium varium, R. Br. Prod. p. I65; Benth. Fl. Austral. vii, p. 674; Hook. \& Grev. Ic. Filic. t. I 2.

Lycopodium Billardieri, Spring, Monogr. Lycopod. i, p. 57 ; ii, p. 24.

New Zealand, Tasmania, Victoria, Polynesia, and South Africa.

163. Psilotum triquetrum, Sw. Syn. Filic. p. I87; Benth. Fl. Austral. vii, p. 68I ; Hook. Gen. Filic. t. 87; Hook. Filic. Exot. t. 63 ; F. Muell. Fragm. x, p. I 88 ; Hemsl. Rep. Voy. Chall. Bot. i, 3, p. 258.

Asia, Africa, America, and Australia, and the most remote islands of Polynesia.

Mueller mentions having specimens of this from the island, three feet long.

164. Tmesipteris tannensis, Bernh. in Schrad. Journ. ii (I800), p. I3I, t. 2, f. 5 ; Benth. Fl. Austral. vii, p. 680; Labill. P1. Nov. Holl. ii, p. 105, t. 252 ; F. Muell. Fragm. ix, p. 78 .

Tmesipteris Forsteri, Endl.; Hook. f. Handb. Fl. N. Zeal. p. $39 \mathrm{I}$.

New Zealand, Norfolk Island, Tasmania, Eastern Australia, and Polynesia.

\section{Selaginellaceae.}

165. Selaginella uliginosa, Spring, Monogr. Lycopod. ii, p. 60 ; Benth. Fl. Austral. vii, p. 678 .

Lycopodium uliginosum, Labill. P1. Nov. Holl. ii, p. I04, t. 25 I. Tasmania, and Australia except the north.

LXIX. FILICES.

166. Cyathea brevipinna, Baker, in Benth. Fl. Austral. vii, p. 709 . 
Endemic.

This is most likely the plant referred in Mueller's list (Fragm. ix, p. 78$)$ to $C$. medullaris, Sw.

167. Cyathea Macarthurii, F. Muell. Fragm. vii, p. I77; Benth. Fl. Austral. vii, p. 708.

Cyathea Moorei, Hook. \& Baker, Synop. Fil. p. 453.

Hemitelia Macarthurii, F. Muell. Fragm. viii, p. I76 ; ix, p. 78 .

Endemic.

168. Hemitelia Moorei, Baker, in Gard. Chron. (I872), p. 252 ; Benth. Fl. Austral. vii, p. 709 ; F. Muell. Fragm. ix, p. 78 .

Endemic.

169. Alsophila australis, R. Br. Prod. p. I58, var.? nigrescens; Benth. Fl. Austral. vii, p. 7 I ०.

Alsophila excelsa, R. Br. in Endl. Prod. Fl. Norf. p. I6 ; Hook. Spec. Filic. i. p. 49, t. I 8 a ; Gard. Chron. I87 I, p. 6 Io; F. Muell. Fragm. ix, p. 78.

Tasmania, South and East Australia, and Norfolk Island.

170. Dicksonia nephrodioides, F. Muell. Census, ed. I, p. 137 ; F. Muell. Fragm. ix, p. 78.

Deparia nephrodioides, Baker, in Gard. Chron. (1872), p. 253 ; Benth. Fl. Austral. vii, p. 7 I4; Hook. Ic. P1. t. I608.

Davallia nephrodioides, F. Muell. Fragm. x, p. I04. Endemic.

171. Hymenophyllum flabellatum, Labill. P1. Nov. Holl. ii, p. IOI, t. 250 ; Benth. Fl. Austral. vii, p. 705 .

Hymenophyllum nitens, R. Br. Prod. p. I59; Hook. \& Grev. Ic. Filic. t. 197.

New Zealand, Tasmania, Eastern Australia, and Polynesia.

172. Hymenophyllum minimum, A. Rich. Fl. Nouv. Zél. p. I9, t. I4, f. 2 ; Benth. Fl. Austral. vii, p. 706.

New Zealand and Auckland Isles.

173. Hymenophyllum multifidum, Sw. Syn. Filic. pp. I49, 
378 ; Benth. Fl. Austral. vii, p. 707 ; Hook. \& Grev. Ic. Filic. t. 167 .

New Zealand and Southern Polynesia.

174. Hymenophyllum pumilum, C. Moore, in Hook. \& Baker, Synop. Fil. p. 464 ; Benth. Fl. Austral. vii, p. 706 ; C. Moore, Handb. Fl. N. S. W. p. 504. Hymenophyllum Moorei, Baker, in Hook. \& Baker, Synop. Fil. p. 464 .

New South Wales.

175. Hymenophyllum tunbridgense, Sm. in Roem. Archiv, i, p. $5^{6}$; Benth. Fl. Austral. vii, p. 706 ; Bedd. Ferns S. India, t. 265 ; F. Muell. Fragm. ix, p. 78 .

Hymenophyllum cupressiforme, Labill. Pl. Nov. Holl. ii, p. 102, t. 250.

Almost cosmopolitan in temperate and subtropical regions.

176. Trichomanes apiifolium, Presl, Hymenophyllaceae, p. 44 ; Benth. Fl. Austral. vii, p. 703.

Trichomanes meifolium, Bory, in Willd. Sp. Pl. v, p. 509; F. Muell. Fragm. ix, p. 78 .

Trichomanes polyanthos, Hook. Ic. P1. t. 703 .

Trichomanes Bauerianum, Endl. Prodr. Fl. Norf. p. I7. Eastern Australia, Norfolk Island, Polynesia, and Malaya.

17\%. Davallia dubia, R. Br. Prod. p. I 57 ; Benth. Fl. Austral. vii, p. 716.

Dicksonia dubia, Gaudich. in Freyc. Voy. Bot. p. $3^{67}$; Hook. Spec. Filic. i, p. 7I, t. 24.

Tasmania and South and East Australia.

178. Adiantum aethiopicum, L. Syst. Nat. ed. X, n. I5; Benth. Fl. Austral. vii, p. 724 ; Bedd. Ferns S. India, t. 5 ; F. Muell. Fragm. ix, p. 78 .

Adiantum trigonum, Labill. Pl. Nov. Holl. ii, p. 99, t. 248. Widely dispersed in tropical and temperate regions of the Old World and Western America.

179. Adiantum hispidulum, Sw. Syn. Filic. pp. I24, 321 ; Benth. Fl. Austral. vii, p. 725 ; Bedd. Ferns S. Ind. t. 3 ; F. Muell. Fragm. ix, p. 78 .

New Zealand, Australasia, Polynesia, Asia, and Africa. 
180. Hypolepis tenuifolia, Bernh. in Schrad. Journ. ii ( 1800$)$, p. 24 ; Benth. Fl. Austral. vii, p. 726 ; Hook. Spec. Filic. ii, p. 6o, tt. 89-90; F. Muell. Fragm. ix, p. 78 .

New Zealand, Eastern Australia, Polynesia, and Malaya.

181. Cheilanthes tenuifolia, Sw. Syn. Filic. p. I26; Benth. Fl. Austral. vii, p. 726 ; Hook. Spec. Filic. ii, p. 82, t. 87 ; F. Muell. Fragm. ix, p. 78 .

New Zealand, throughout Australia, Malaya, and India.

182. Pteris aquilina, L. Sp. Pl. p. I075, var. esculenta; Benth. Fl. Austral. vii, p. $73^{\mathrm{I}}$; Bedd. Ferns S. Ind. t. 42 ; F. Muell. Fragm. ix, p. 78 .

Pteris esculenta, Forst. f. Prod. p. 79; Labill. Pl. Nov. Holl. ii, p. 95, t. 244.

The typical form is almost cosmopolitan, but the variety esculenta is confined to the southern hemisphere.

183. Pteris comans, Forst. f. Prod. p. 79; Benth. Fl. Austral. vii, p. 733 ; Hemsl. Rep. Voy. Chall. Bot. i, 3, p. 70 ; F. Muell. Fragm. ix, p. 78 .

Pteris Endlicheriana, Agardh. Sp. Gen. Pterid. p. 66 ; Hook. Ic. Pl. t. 973.

New Zealand, Tasmania, South and East Australia, and Polynesia.

184. Pteris falcata, R. Br. Prod. p. I54; Benth. Fl. Austral. vii, p. 729 ; F. Muell. Fragm. ix, p. 78 .

Pellaea seticaulis, Hook. Ic. P1. t. 207.

Platyloma falcatum, J. Sm. Cult. Ferns, p. $3^{2}$; Bedd. Ferns S. Ind. t. 22.

New Zealand, Tasmania, South and East Australia, Malaya, and India.

185. Pteris incisa, Thunb. Prod. Fl. Cap. p. I7I ; Benth. Fl. Austral. vii, p. $73^{2}$; Hemsl. Rep. Voy. Chall. Bot. i. 3, p. 70 ; F. Muell. Fragm. ix, p. 78 .

Pteris vespertilionis, Labill. P1. Nov. Holl. ii, p. 96, t. 245 .

Tropical regions generally and southern extratropical countries.

186. Pteris tremula, R. Br. Prod. p. I 54; Benth. Fl. Austral. vii, p. 73I ; Hook. Spec. Filic. ii, p. I74, t. I 20. 
Pteris arguta, F. Muell. Fragm. ix, p. 78, vix Ait.

New Zealand, Tasmania, South and East Australia, Norfolk Island, and Western Polynesia.

18\%. Lomaria attenuata, Willd. Sp. P1. v, 290; Benth. Fl. Austral. vii, p. $73^{6}$; Hemsl. Rep. Voy. Chall. Bot. i, 3, p. 71 .

Kermadec Islands, Polynesia, Mascarene Islands, South Africa, and South America, but not known either from Australia or New Zealand.

188. Lomaria capensis, Willd. Sp. P1. v, p. 29I; Benth. Fl. Austral. vii, p. 737 ; Hemsl. Rep. Voy. Chall. Bot. i, 3, p. 73 ; F. Muell. Fragm. ix, p. 78.

Lomaria procera, Spreng. Syst. Veg. iv, p. 65 ; Hook. Ic. Pl. t. 427 ; Gard. Ferns, t. 53.

Very widely dispersed in tropical and southern extratropical regions.

189. Lomaria Fullagari, F. Muell. Fragm. viii p. 157 ; ix, p. 78 ; Benth. Fl. Austral. vii, p. 737.

Lomaria auriculata, Baker, Synop. Fil. p. 48I.

Endemic.

190. Doodia aspera, R. Br. Prod. p. I5I ; Benth. Fl. Austral. vii, p. 74I ; Hook. Exot. Fl. t. 8.

Woodwardia aspera, Mett.; Bailey, Queensland Ferns, p. 27. Victoria, New South Wales, and Queensland.

191. Asplenium falcatum, Lam. Encyc. Meth. i, p. $3 \circ 3$; Benth. Fl. Austral. vii, p. 746 ; Bedd. Ferns S. Ind. t. I4I ; F. Muell. Fragm. ix, p. 78 .

New Zealand, Eastern Australia, Polynesia, tropical Asia and Africa.

192. Asplenium melanochlamys, Hook. Sp. Filic. iii, p. 259; Synop. Fil. p. 239 ; Benth. Fl. Austral. vii, p. 75I ; F. Muell. Fragm. ix, p. 78 .

Endemic.

193. Asplenium obtusatum, Forst.; Hook. Syn. Fil. p. 207 ; Hook. Fil. Exot. t. 46 ; Benth. Fl. Austral. vii, p. 747 (var. incisum). 
Asplenium marinum cum pluribus varietatibus, F. Muell. Fragm. ix, p. 78.

Tasmania, New South Wales, New Zealand, Norfolk Island, and extratropical South America.

194. Asplenium Nidus, L. Sp. Pl. p. I079; Benth. Fl. Austral. vii, p. 744; Hemsl. Rep. Voy. Chall. Bot. i, 3, p. 253 ; Bot. Mag. t. 3 I01 ; F. Muell. Fragm. ix, p. 78.

Asplenium australasicum, Hook. Filic. Exot. t. 88.

Widely spread in the warmer parts of the Old World, including Eastern Australia and Polynesia, eastward to Mangaia, Elizabeth Island, Tahiti, and the Sandwich Islands.

195. Asplenium pteridioides, Baker, Syn. Filic. p. 488; Benth. Fl. Austral. vii, p. 749 ; Hook. Ic. Pl. t. I649.

Endemic.

196. Aspidium apicale, Baker, in Benth. Fl. Austral. vii, p. $75^{8}$.

Endemic.

Mueller's list (Fragm. ix, p. 78) includes the widely-spread A. aculeatum, but I have seen no specimen.

197. Aspidium capense, Willd. Sp. P1. v, p. 267 ; Benth. Fl. Austral. vii, p. $75^{8}$; Hemsl. Rep. Voy. Chall. Bot. i, 3, p. 75 .

Aspidium coriaceum, Sw. Syn. Fil. p. 57 ; Hook. Sp. Fil. iv, p. 32 .

Widely spread in tropical and southern extratropical regions, including the remote islands of Tristan d'Acunha and St. Paul.

198. Aspidium cordifolium, Sw. Syn. Filic. p. 45 ; Benth. Fl. Austral. vii, p. 754 .

Aspidium tuberosum, Bory; F. Muell. Fragm. v, p. I36 ; ix, p. 78 .

Nephrolepis tuberosa, Presl, Tent. Pterid. p. 79; Bedd. Ferns S. Ind. t. 92; Hook. f. Handb. Fl. N. Zeal. p. 379.

Northern Island New Zealand, New South Wales, Queensland, and generally spread in the tropics. 
199. Aspidium molle, Sw. Syn. Filic. p. 46 ; Benth. Fl. Austral. vii, p. 756 .

Polypodium molle, Jacq. Ic. Rar. t. 64.0.

Nephrodium molle, R. Br. Prod. p. 149; Bedd. Ferns S. Ind. t. 84; Hemsl. Rep. Voy. Chall. Bot. i, 3, p. 254.

Generally dispersed in warm countries.

200. Polypodium australe, Mett. Filic. Hort. Bot. Lips. (1856) p. $3^{6}$; Benth. Fl. Austral. vii, p. 762 ; Hook. f. Handb. F1. N. Zeal. p. 380 ; Hemsl. Rep. Voy. Chall. Bot. i, 2, p. 196; F. Muell. Fragm. ix, p. 78 .

Extratropical South America, Tasmania, Victoria, New South Wales, Queensland, New Zealand, and Chatham, Lord Auckland, Marion, Amsterdam, and Tristan d'Acunha Islands.

201. Polypodium confluens, R. Br. Prod. p. 146 ; Benth. Fl. Austral vii, p. 767 ; Fée, Fil. Bras. t. 26.

Eastern Australia, Norfolk Island, and New Caledonia.

Mueller includes in his list (Fragm. ix, p. 78) P. serpens, Forst., a species common to Eastern Australia, New Zealand, and Polynesia, which has been confused with $P$. confluens.

202. Polypodium Hookeri, Brackenr. Bot. Wilk. Exped. Filic. p. 4 ; Benth. Fl. Austral. vii, p. 763 ; F. Muell. Fragm. ix, p. 78 .

Polypodium setigerum, Hook. \& Arn. Bot. Beech. Voy. p. IO3, t. 21 .

Eastern Australia, the Philippine and Sandwich Islands.

203. Polypodium punctatum, Thunb. Fl. Jap. p. 337 ; Benth. Fl. Austral. vii, p. 764 ; Hillebr. Fl. Haw. p. 553.

Polypodium rugulosum, Labill. Pl. Nov. Holl. ii, p. 92, t. 24I ; Bedd. Ferns S. Ind. t. I70; Hook. f. Handb. Fl. N. Zeal. p. $3^{8 \mathrm{I}}$.

Widely spread in the southern hemisphere, including the Chatham, Lord Auckland, Juan Fernandez, St. Helena, and Tristan d'Acunha Islands, and extending northward to Japan. 
204. Polypodium pustulatum, Forst. f. Prod. p. 8I ; Benth. Fl. Austral. vii, p. 769 ; Hook. f. Handb. Fl. N. Zeal. p. $3^{82}$. Polypodium scandens, Labill. P1. Nov. Holl. ii, p. 9I, t. 240. Polypodium Billardieri, R. Br.; Muell. Fragm. ix, p. 78 .

New Zealand, Norfolk Island, Tasmania, and Eastern Australia.

205. Polypodium tenellum, Forst. f. Prod. p. 440 ; Benth. Fl. Austral. vii, p. 764 ; F. Muell. Fragm. ix, p. 78.

Arthropteris tenella, J. Sm. in Hook. f. Fl. N. Zeal. t. 82.

New Zealand, Norfolk Island, New Caledonia, and Eastern Australia.

206. Notholaena distans, R. Br. Prod. p. I46; Benth. Fl. Austral. vii, p. 774 ; Hook. Ic. Pl. t. 980.

New Zealand, Norfolk Island, New Caledonia, Australia except the north, and Polynesia.

207. Platycerium alcicorne, Desv. in Mém. Soc. Linn. Par. vi (1827), p. 213; Benth. Fl. Austral.vii, p. 780 ; Gard. Chron. I872, p. 5I I F. Muell. Fragm. ix, p. 78.

Acrostichum alcicorne, Sw. Syn. Filic. p. 17; Bot. Reg. t. 262.

Eastern Australia and the Mascarene Islands.

208. Todea Moorei, Baker, in Journ. Bot. xi (1873), p. I6 ; Benth. Fl. Austral. vii, p. 700 ; F. Muell. Fragm. ix, p. 78 .

Endemic.

209. Marattia fraxinea, Sm. Ic. Ined. t. 48 ; Benth. Fl. Austral. vii, p. 695 ; Bedd. Ferns S. Ind. t. 79.

Marattia salicina, Sm.; F. Muell. Fragm. ix, p. 78 ; x, p. II 8.

New Zealand, Eastern Australia, Polynesia, and widely dispersed in tropical Asia and Africa. 
Table showing the Distribution of the Genera REPRESENTED IN THE ISLAND.

\begin{tabular}{|c|c|c|c|c|c|c|c|c|c|c|}
\hline & & & & & 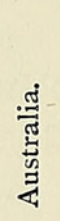 & 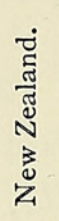 & 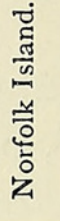 & 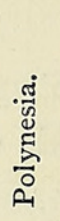 & 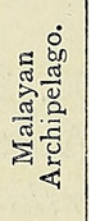 & 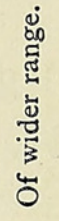 \\
\hline I. Clematis & $\ldots$ & $\ldots$ & $\ldots$ & $\ldots$ & I & I & I & I & I & I \\
\hline 2. Drimys & $\ldots$ & $\ldots$ & $\ldots$ & $\ldots$ & I & I & & I & I & I \\
\hline 3. Stephania & $\ldots$ & $\ldots$ & $\ldots$ & ... & I & & & I & I & I \\
\hline 4. Lepidium & & $\ldots$ & $\ldots$ & $\ldots$ & I & I & & I & & I \\
\hline 5. Hymenanthe & & $\ldots$ & ... & $\ldots$ & I & I & I & & & \\
\hline 6. Xylosma & & $\ldots$ & $\cdots$ & $\cdots$ & I & & & I & I & I \\
\hline 7. Pittosporum & & $\ldots$ & ... & $\ldots$ & I & I & I & I & 1 & I \\
\hline 8. Calophyllum & & $\ldots$ & $\ldots$ & $\ldots$ & I & & & I & I & I \\
\hline 9. Hibiscus & $\ldots$ & $\ldots$ & $\ldots$ & $\ldots$ & I & I & I & 1 & I & I \\
\hline I0. Lagunaria & $\ldots$ & $\ldots$ & $\ldots$ & $\ldots$ & I & & I & & & \\
\hline II. Pelargonium & $\ldots$ & $\ldots$ & $\ldots$ & $\ldots$ & I & I & & & & I \\
\hline 12. Oxalis & $\ldots$ & $\ldots$ & $\ldots$ & ... & I & I & I & I & I & I \\
\hline I3. Melicope & $\ldots$ & $\ldots$ & $\ldots$ & $\ldots$ & I & I & & I & & \\
\hline 14. Evodia & $\ldots$ & $\ldots$ & $\ldots$ & ... & I & & & I & I & I \\
\hline 15. Zanthoxylum & & $\cdots$ & $\cdots$ & $\ldots$ & I & & I & & I & I \\
\hline I6. Acronychia & $\ldots$ & $\ldots$ & $\ldots$ & $\ldots$ & I & I & & I & I & I \\
\hline 17. Dysoxylum & & $\ldots$ & $\ldots$ & $\ldots$ & I & I & & I & I & 1 \\
\hline 18. Elaeodendror & & $\ldots$ & $\ldots$ & $\ldots$ & I & & I & I & I & I \\
\hline 19. Cupania & $\ldots$ & $\ldots$ & $\ldots$ & $\ldots$ & I & & & I & I & I \\
\hline 20. Atalaya & $\ldots$ & $\ldots$ & $\ldots$ & $\ldots$ & I & & & & I & \\
\hline 21. Dodonaea & $\ldots$ & $\ldots$ & ... & $\ldots$ & I & I & I & I & I & I \\
\hline 22. Carmichaelia & $\ldots$ & $\ldots$ & $\ldots$ & $\ldots$ & & I & & & & \\
\hline 23. Mucuna & $\ldots$ & $\ldots$ & $\ldots$ & $\ldots$ & I & & & I & I & I \\
\hline 24. Canavalia & $\ldots$ & $\ldots$ & $\ldots$ & $\ldots$ & I & & I & I & I & I \\
\hline 25. Vigna... & $\ldots$ & $\ldots$ & $\ldots$ & $\ldots$ & I & & & I & I & I \\
\hline 26. Sophora . & & $\ldots$ & $\cdots$ & ... & I & I & & I & & \\
\hline 27. Caesalpinia & $\ldots$ & $\ldots$ & $\ldots$ & $\ldots$ & I & & I & I & I & I \\
\hline 28. Colmeiroa & & $\ldots$ & $\ldots$ & $\ldots$ & & & & & & \\
\hline 29. Leptospermu & & $\ldots$ & $\ldots$ & $\ldots$ & I & I & & & I & I \\
\hline 30. Melaleuca & $\ldots$ & $\ldots$ & $\ldots$ & $\cdots$ & I & & & & I & I \\
\hline 3I. Acicalyptus & $\ldots$ & $\ldots$ & $\cdots$ & $\ldots$ & & & & I & & \\
\hline 32. Metrosideros & & $\ldots$ & $\ldots$ & $\ldots$ & I & I & & I & I & I \\
\hline 33. Passiflora & ... & $\ldots$ & $\ldots$ & $\ldots$ & I & I & I & 1 & I & I \\
\hline 34. Sicyos... & & $\ldots$ & $\ldots$ & ... & I & I & I & I & I & I \\
\hline 35. Mesembryant & themur & & $\ldots$ & $\ldots$ & I & I & I & & & I \\
\hline 36. Tetragonia & $\ldots$ & $\ldots$ & $\ldots$ & $\ldots$ & I & I & 1 & I & & I \\
\hline 37. Sesuvium & & $\ldots$ & $\ldots$ & $\ldots$ & I & & & 1 & & I \\
\hline 38. Hydrocotyle & $\ldots$ & $\ldots$ & $\ldots$ & $\ldots$ & I & I & & I & I & I \\
\hline 39. Apium & $\ldots$ & $\ldots$ & $\ldots$ & $\ldots$ & I & I & I & I & & I \\
\hline \multirow[t]{2}{*}{ 40. Panax... } & $\cdots$ & $\cdots$ & ... & $\ldots$ & I & I & & I & I & I \\
\hline & & & & & 37 & 23 & I6 & $3^{\circ}$ & 30 & 33 \\
\hline
\end{tabular}




\begin{tabular}{|c|c|c|c|c|c|c|c|c|c|c|}
\hline & & & & & 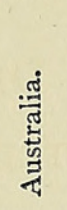 & 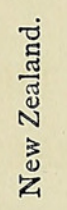 & 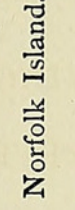 & 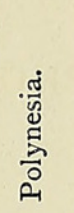 & 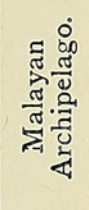 & 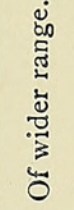 \\
\hline & & & & & 37 & 23 & I6 & 30 & 30 & 33 \\
\hline 4I. Randia & $\cdots$ & $\ldots$ & $\ldots$ & $\ldots$ & I & & & I & I & I \\
\hline 42. Psychotria & $\ldots$ & $\ldots$ & $\ldots$ & $\ldots$ & I & & & I & I & I \\
\hline 43. Coprosma & $\ldots$ & $\ldots$ & $\ldots$ & $\ldots$ & I & I & I & I & I & I \\
\hline 44. Brachycome . & $\ldots$ & $\ldots$ & $\ldots$ & $\ldots$ & I & I & & & & \\
\hline 45. Olearia & $\ldots$ & $\ldots$ & $\ldots$ & $\ldots$ & I & I & & & & \\
\hline 46. Gnaphalium . & $\ldots$ & $\ldots$ & $\ldots$ & $\ldots$ & I & I & I & I & I & I \\
\hline 47. Cassinia & $\ldots$ & $\ldots$ & $\ldots$ & $\ldots$ & I & I & & I & & \\
\hline 48. Wedelia & $\ldots$ & $\ldots$ & $\ldots$ & $\ldots$ & I & & I & I & I & I \\
\hline 49. Bidens . & $\ldots$ & $\ldots$ & $\ldots$ & $\ldots$ & I & 1 & I & 1 & I & I \\
\hline 50. Erechthites . & $\ldots$ & $\ldots$ & $\ldots$ & $\ldots$ & 1 & I & & & 1 & I \\
\hline 5I. Senecio . & $\ldots$ & $\ldots$ & $\ldots$ & $\ldots$ & I & I & I & I & I & I \\
\hline 52. Scaevola & $\ldots$ & $\ldots$ & $\ldots$ & $\ldots$ & I & I & & I & I & I \\
\hline 53. Lobelia & $\ldots$ & $\ldots$ & $\ldots$ & $\ldots$ & I & I & I & I & I & I \\
\hline 54. Wahlenbergia & & $\ldots$ & $\ldots$ & $\ldots$ & I & I & & I & I & I \\
\hline 55. Leucopogon & & $\ldots$ & $\ldots$ & $\ldots$ & I & I & & I & I & I \\
\hline 56. Dracophyllum & & $\ldots$ & $\ldots$ & $\ldots$ & I & I & & I & & \\
\hline 57. Myrsine . & $\ldots$ & $\ldots$ & $\ldots$ & $\ldots$ & I & I & I & I & I & I \\
\hline 58. Aegiceras . & $\ldots$ & $\ldots$ & $\ldots$ & $\ldots$ & I & & & I & I & I \\
\hline 59. Sideroxylon . & $\ldots$ & $\ldots$ & $\ldots$ & $\ldots$ & I & I & & I & I & I \\
\hline 6o. Symplocos . & $\ldots$ & $\ldots$ & $\ldots$ & $\ldots$ & I & & & I & I & I \\
\hline 6r. Jasminum & $\ldots$ & $\ldots$ & $\ldots$ & $\ldots$ & I & & I & I & I & I \\
\hline 62. Notelaea & $\ldots$ & $\ldots$ & $\ldots$ & $\ldots$ & I & & & & & \\
\hline 63 . Olea ... & $\ldots$ & $\ldots$ & $\ldots$ & $\ldots$ & I & I & I & I & I & I \\
\hline 64. Alyxia & $\ldots$ & $\ldots$ & $\ldots$ & $\ldots$ & I & & I & I & I & I \\
\hline 65. Ochrosia & $\ldots$ & $\ldots$ & $\ldots$ & $\ldots$ & I & & & I & I & I \\
\hline 66. Lyonsia & $\ldots$ & $\ldots$ & $\ldots$ & $\ldots$ & I & & & & & \\
\hline 67. Vincetoxicum & & $\ldots$ & $\ldots$ & $\ldots$ & I & & & & I & I \\
\hline 68. Tylophora & $\ldots$ & $\ldots$ & $\ldots$ & $\ldots$ & I & & & I & I & I \\
\hline 69. Marsdenia . & $\ldots$ & $\ldots$ & $\ldots$ & $\ldots$ & I & & & & I & I \\
\hline 70. Geniostoma . & $\ldots$ & $\ldots$ & $\ldots$ & $\ldots$ & I & I & & I & I & I \\
\hline 7I. Solanum : & $\ldots$ & $\cdots$ & $\cdots$ & $\ldots$ & I & 1 & I & I & I & I \\
\hline 72. Ipomoea & $\ldots$ & $\ldots$ & $\ldots$ & $\ldots$ & I & I & I & I & I & I \\
\hline 73. Calystegia & $\ldots$ & $\ldots$ & $\ldots$ & $\ldots$ & 1 & I & I & I & & I \\
\hline 74. Negria & & & & & & & & & & \\
\hline 75. Tecoma & $\ldots$ & $\ldots$ & $\ldots$ & $\ldots$ & I & & & I & I & $\mathbf{I}$ \\
\hline 76. Eranthemum. & $\ldots$ & $\ldots$ & $\ldots$ & $\ldots$ & I & & & I & I & I \\
\hline 77. Myoporum. & $\ldots$ & $\ldots$ & $\ldots$ & $\ldots$ & I & I & I & I & I & I \\
\hline $7^{Q}$. Avicennia & $\cdots$ & $\begin{array}{l}\cdots \\
\cdots\end{array}$ & $\ldots$ & $\ldots$ & I & I & & I & I & I \\
\hline 79. Westringia & $\ldots$ & $\ldots$ & $\ldots$ & $\ldots$ & I & & & & & \\
\hline 80. Plantago. & $\cdots$ & $\ldots$ & $\begin{array}{l}\cdots \\
\ldots\end{array}$ & $\ldots$ & I & I & & I & I & I \\
\hline 8I. Boerhaavia & $\ldots$ & $\ldots$ & $\ldots$ & $\ldots$ & 1 & & & I & I & I \\
\hline 82. Pisonia & $\ldots$ & $\ldots$ & $\ldots$ & $\ldots$ & I & I & I & I. & I & I \\
\hline 83. Rhagodia & & $\ldots$ & $\ldots$ & $\ldots$ & I & & & & I & I \\
\hline 84. Atriplex & & $\ldots$ & $\ldots$ & $\ldots$ & I & I & & I & I & I \\
\hline 85. Achyranthes. & & $\ldots$ & $\ldots$ & $\ldots$ & I & & & I & I & I \\
\hline \multirow{2}{*}{\multicolumn{2}{|c|}{ 86. Muehlenbeckia }} & $\ldots$ & $\ldots$ & $\ldots$ & I & I & & & & I \\
\hline & & & & & 82 & 49 & $3 I$ & 65 & 66 & 71 \\
\hline
\end{tabular}




\begin{tabular}{|c|c|c|c|c|c|c|c|c|c|c|}
\hline & & & & & 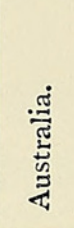 & 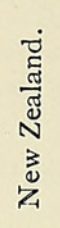 & 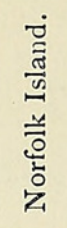 & 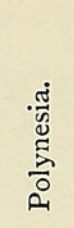 & 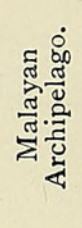 & 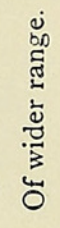 \\
\hline & & & & & 82 & 49 & $3 \mathrm{I}$ & $6_{5}$ & 66 & $7 \mathrm{I}$ \\
\hline 87. Piper ... & $\ldots$ & $\ldots$ & $\ldots$ & ... & I & I & I & I & I & I \\
\hline 88. Peperomia & $\ldots$ & $\ldots$ & $\ldots$ & $\ldots$ & I & & & I & I & I \\
\hline 89. Cryptocarya & $\ldots$ & $\ldots$ & $\ldots$ & $\ldots$ & I & & & I & I & I \\
\hline 90. Pimelea & $\ldots$ & $\ldots$ & $\ldots$ & $\ldots$ & I & I & & & & \\
\hline 9I. Exocarpus & $\ldots$ & $\ldots$ & $\ldots$ & $\ldots$ & I & I & I & I & I & \\
\hline 92. Viscum & $\ldots$ & $\ldots$ & $\ldots$ & $\ldots$ & I & I & I & I & I & I \\
\hline 93. Euphorbia & $\ldots$ & $\ldots$ & $\ldots$ & $\ldots$ & I & I & I & I & I & I \\
\hline 94. Hemicyclia & $\ldots$ & $\ldots$ & $\ldots$ & $\ldots$ & I & & & & I & I \\
\hline 95. Baloghia & $\ldots$ & $\ldots$ & $\ldots$ & $\ldots$ & I & & I & I & & \\
\hline 96. Homalanthus & & $\ldots$ & $\ldots$ & $\ldots$ & I & & & I & I & I \\
\hline 97. Celtis ... & $\ldots$ & $\ldots$ & $\ldots$ & $\ldots$ & I & & I & I & I & I \\
\hline 98. Malaisia & $\ldots$ & $\ldots$ & $\ldots$ & $\ldots$ & I & & & I & I & \\
\hline 99. Ficus ... & $\ldots$ & $\ldots$ & $\ldots$ & $\ldots$ & I & & & I & I & I \\
\hline I00. Elatostema & $\ldots$ & $\ldots$ & $\ldots$ & $\ldots$ & I & I & I & I & I & I \\
\hline IоI. Boehmeria & $\ldots$ & $\ldots$ & $\ldots$ & $\ldots$ & & & I & I & I & I \\
\hline I02. Parietaria & $\ldots$ & $\ldots$ & $\ldots$ & $\ldots$ & I & I & & I & I & I \\
\hline 103. Dendrobium & $\ldots$ & $\ldots$ & $\ldots$ & $\ldots$ & I & I & & I & I & I \\
\hline 104. Bulbophyllun & & $\ldots$ & $\ldots$ & $\ldots$ & I & I & & I & I & I \\
\hline I05. Cleisostoma & $\ldots$ & $\ldots$ & $\ldots$ & $\ldots$ & I & & & & I & I \\
\hline I06. Microtis & $\ldots$ & $\ldots$ & $\ldots$ & $\ldots$ & I & I & & I & I & I \\
\hline 107. Crinum & $\ldots$ & $\ldots$ & $\ldots$ & $\ldots$ & I & & I & I & I & I \\
\hline I08. Moraea & $\ldots$ & $\ldots$ & $\ldots$ & $\ldots$ & & & & & & I \\
\hline I09. Smilax & $\ldots$ & $\ldots$ & $\ldots$ & $\ldots$ & I & & & I & I & I \\
\hline I IO. Geitonoplesiv & & $\ldots$ & $\ldots$ & $\ldots$ & I & & I & I & I & I \\
\hline 1Iı. Dianella & $\ldots$ & $\ldots$ & $\ldots$ & $\ldots$ & I & I & I & I & I & I \\
\hline I I2. Commelina & $\ldots$ & $\ldots$ & $\ldots$ & $\ldots$ & I & & I & I & I & I \\
\hline II3. Flagellaria & $\ldots$ & $\ldots$ & $\ldots$ & $\ldots$ & I & & & I & I & I \\
\hline I14. Juncus & $\ldots$ & $\ldots$ & $\ldots$ & $\ldots$ & I & I & & I & I & I \\
\hline I I 5. Luzula & $\ldots$ & $\ldots$ & $\ldots$ & $\ldots$ & 1 & I & & I & I & I \\
\hline II6. Hedyscepe & $\ldots$ & $\ldots$ & $\ldots$ & $\ldots$ & & & & & & \\
\hline I 17. Clinostigma & $\ldots$ & $\ldots$ & $\ldots$ & $\ldots$ & & & & I & & \\
\hline II 8 . Howea & $\ldots$ & $\ldots$ & $\ldots$ & $\ldots$ & & & & & & \\
\hline II 9. Pandanus & $\ldots$ & $\ldots$ & $\ldots$ & $\ldots$ & I & & I & I & I & I \\
\hline I 20. Cyperus & $\ldots$ & $\ldots$ & $\ldots$ & $\ldots$ & I & I & I & I & I & I \\
\hline I2I. Scirpus & $\ldots$ & $\ldots$ & $\ldots$ & $\ldots$ & I & I & I & I & I & I \\
\hline 122. Gahnia & $\ldots$ & $\ldots$ & $\ldots$ & $\ldots$ & I & I & & I & I & \\
\hline I23. Uncinia & $\ldots$ & $\ldots$ & $\ldots$ & $\ldots$ & I & I & & I & & I \\
\hline I 24. Carex... & $\ldots$ & $\ldots$ & $\ldots$ & $\ldots$ & I & I & I & I & I & I \\
\hline I25. Panicum & $\ldots$ & $\ldots$ & $\ldots$ & $\ldots$ & I & I & I & I & I & I \\
\hline I26. Oplismenus & $\ldots$ & $\ldots$ & $\ldots$ & $\ldots$ & I & & I & I & I & I \\
\hline I 27. Spinifex & $\ldots$ & $\ldots$ & $\ldots$ & $\ldots$ & I & I & & I & & I \\
\hline I 28. Stipa ... & $\ldots$ & $\ldots$ & $\ldots$ & $\ldots$ & I & I & & & I & I \\
\hline I 29. Sporobolus & $\ldots$ & $\ldots$ & $\ldots$ & $\ldots$ & I & I & & I & I & I \\
\hline I30. Deyeuxia & $\ldots$ & $\ldots$ & $\ldots$ & $\ldots$ & I & I & & I & I & I \\
\hline I3I. Dichelachne & $\ldots$ & $\ldots$ & $\ldots$ & $\ldots$ & I & I & I & & & \\
\hline \multirow[t]{2}{*}{ I32. Cynodon } & $\ldots$ & $\ldots$ & $\ldots$ & $\ldots$ & I & I & & & I & I \\
\hline & & & & & I 23 & 75 & 50 & 102 & 103 & 108 \\
\hline
\end{tabular}




\begin{tabular}{|c|c|c|c|c|c|c|c|c|c|c|}
\hline & & & & & 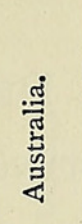 & 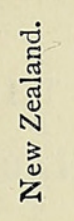 & 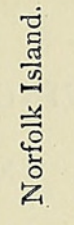 & 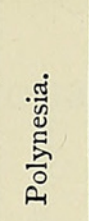 & 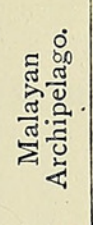 & 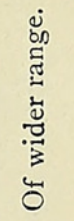 \\
\hline & & & & & I 23 & 75 & 50 & 102 & I03 & 108 \\
\hline I33. Chloris & $\ldots$ & $\ldots$ & $\ldots$ & $\ldots$ & I & & & I & I & I \\
\hline I34. Poa ... & $\ldots$ & $\ldots$ & $\ldots$ & $\ldots$ & & I & & I & I & I \\
\hline I35. Agropyrum & $\ldots$ & $\ldots$ & $\ldots$ & $\ldots$ & I & I & & I & I & I \\
\hline I 36. Lycopodium & $\cdots$ & ... & $\ldots$ & $\ldots$ & I & I & & I & I & I \\
\hline I37. Selaginella & $\ldots$ & $\ldots$ & $\ldots$ & $\ldots$ & I & & & I & I & I \\
\hline I38. Tmesipteris & $\ldots$ & $\ldots$ & $\ldots$ & $\ldots$ & I & I & I & I & & \\
\hline I39. Psilotum & $\ldots$ & $\ldots$ & $\ldots$ & $\ldots$ & I & I & I & I & I & I \\
\hline I40. Cyathea & $\ldots$ & $\ldots$ & $\ldots$ & $\ldots$ & I & I & I & I & I & I \\
\hline I4I. Hemitelia & $\ldots$ & $\ldots$ & $\ldots$ & $\ldots$ & I & I & & I & I & I \\
\hline I42. Alsophila & $\ldots$ & $\ldots$ & $\ldots$ & $\ldots$ & I & I & I & I & I & I \\
\hline I43. Dicksonia & $\ldots$ & $\ldots$ & $\ldots$ & $\ldots$ & I & I & & I & I & I \\
\hline I 44. Hymenophyll & $\operatorname{lum}$ & $\ldots$ & $\ldots$ & ... & I & I & & I & I & $\mathbf{I}$ \\
\hline I45. Trichomanes & $\ldots$ & $\ldots$ & $\ldots$ & $\ldots$ & I & I & I & 1 & I & I \\
\hline I46. Davallia & $\ldots$ & $\ldots$ & $\ldots$ & $\ldots$ & I & I & & I & I & I \\
\hline I 47. Adiantum & $\ldots$ & $\ldots$ & $\ldots$ & $\ldots$ & I & I & I & I & I & I \\
\hline I 48. Hypolepis . & $\ldots$ & $\ldots$ & $\ldots$ & $\ldots$ & I & I & & I & I & I \\
\hline I 49. Cheilanthes . & $\ldots$ & $\ldots$ & $\ldots$ & $\ldots$ & I & I & & I & I & I \\
\hline I 50. Pteris ... . & $\ldots$ & $\ldots$ & $\ldots$ & $\ldots$ & I & I & I & I & I & I \\
\hline I 51. Lomaria & $\ldots$ & $\ldots$ & $\ldots$ & $\ldots$ & I & I & I & I & I & I \\
\hline I52. Doodia & $\ldots$ & $\ldots$ & $\ldots$ & $\ldots$ & I & 1 & I & I & I & I \\
\hline I 53. Asplenium & $\ldots$ & $\ldots$ & $\ldots$ & $\ldots$ & I & I & I & I & I & I \\
\hline I54. Aspidium . & $\ldots$ & $\ldots$ & $\ldots$ & $\ldots$ & I & I & I & I & I & I \\
\hline I55. Polypodium. & $\ldots$ & & $\ldots$ & $\ldots$ & I & I & I & I & I & I \\
\hline I56. Notholaena. & $\ldots$ & $\ldots$ & $\ldots$ & $\ldots$ & I & I & I & I & I & I \\
\hline I57. Platycerium. & $\ldots$ & $\ldots$ & $\ldots$ & $\ldots$ & I & & & & I & I \\
\hline I58. Todea... & $\ldots$ & $\ldots$ & $\ldots$ & $\ldots$ & I & I & & I & & I \\
\hline \multirow[t]{2}{*}{ I59. Marattia } & ... & $\ldots$ & ... & $\ldots$ & I & I & I & I & I & I \\
\hline & & & & & I 50 & 99 & 64 & I 28 & 128 & I 34 \\
\hline
\end{tabular}




\section{Tarle showing the Distribution of the Species}

INHABITING THE ISLAND.

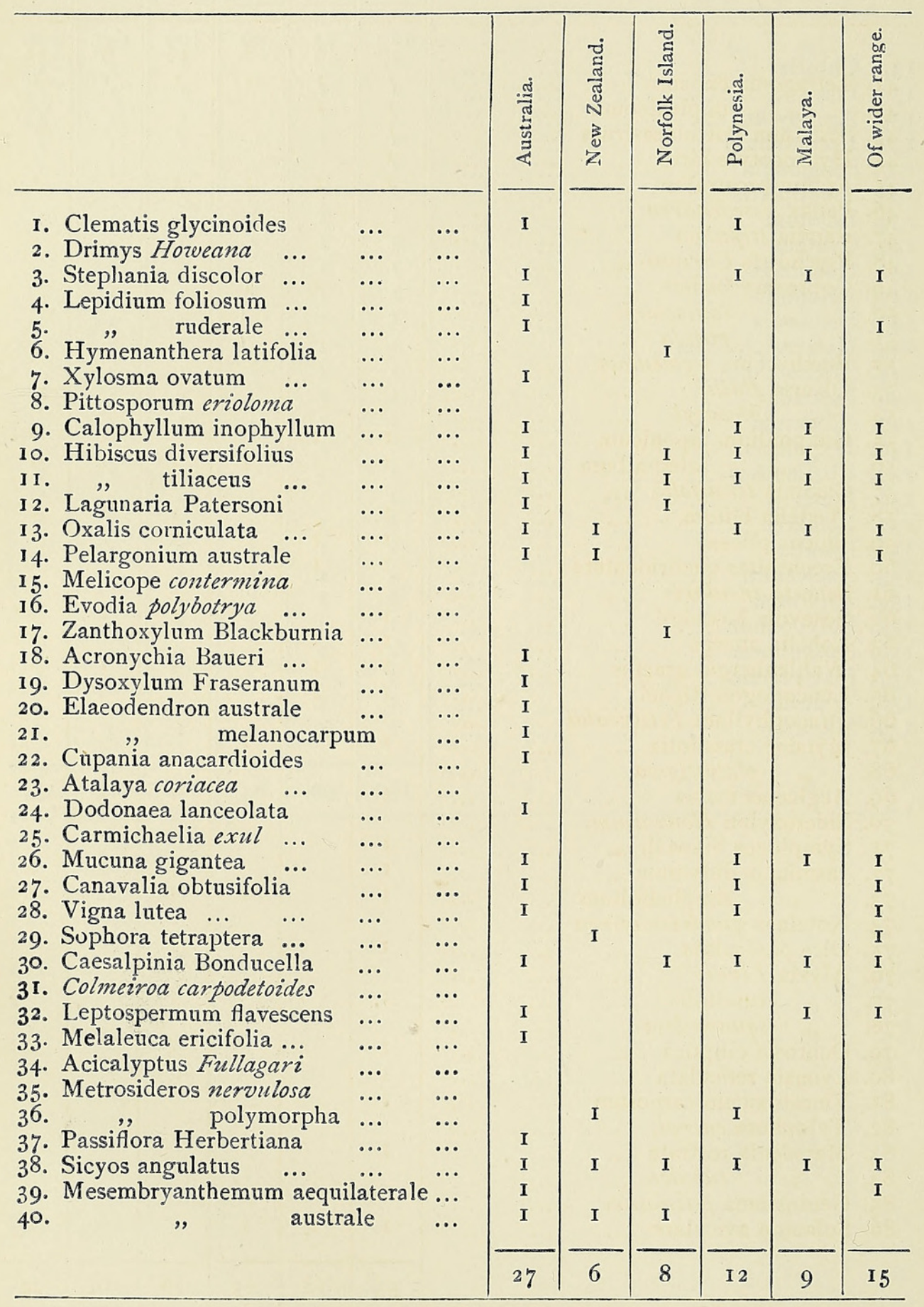




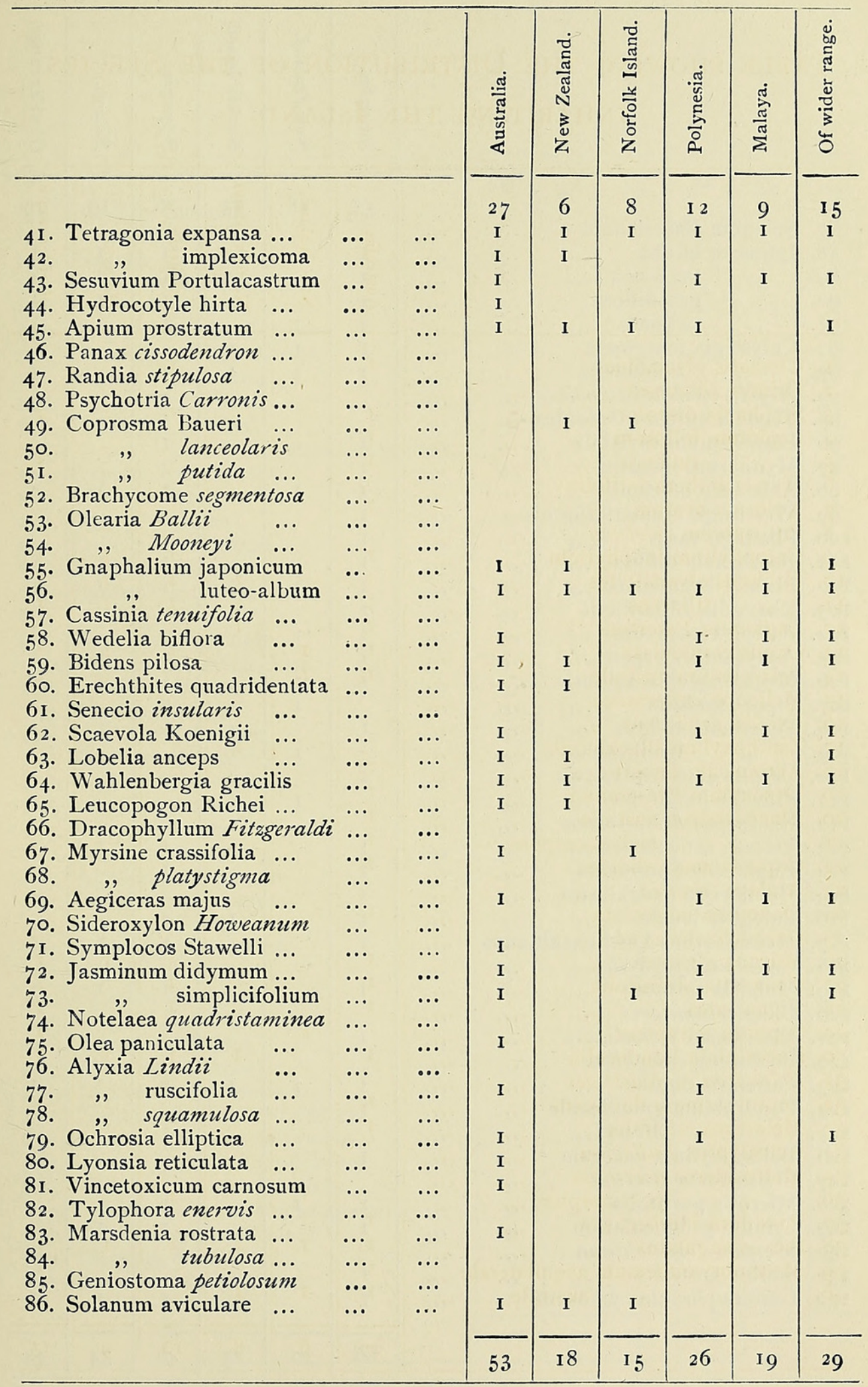




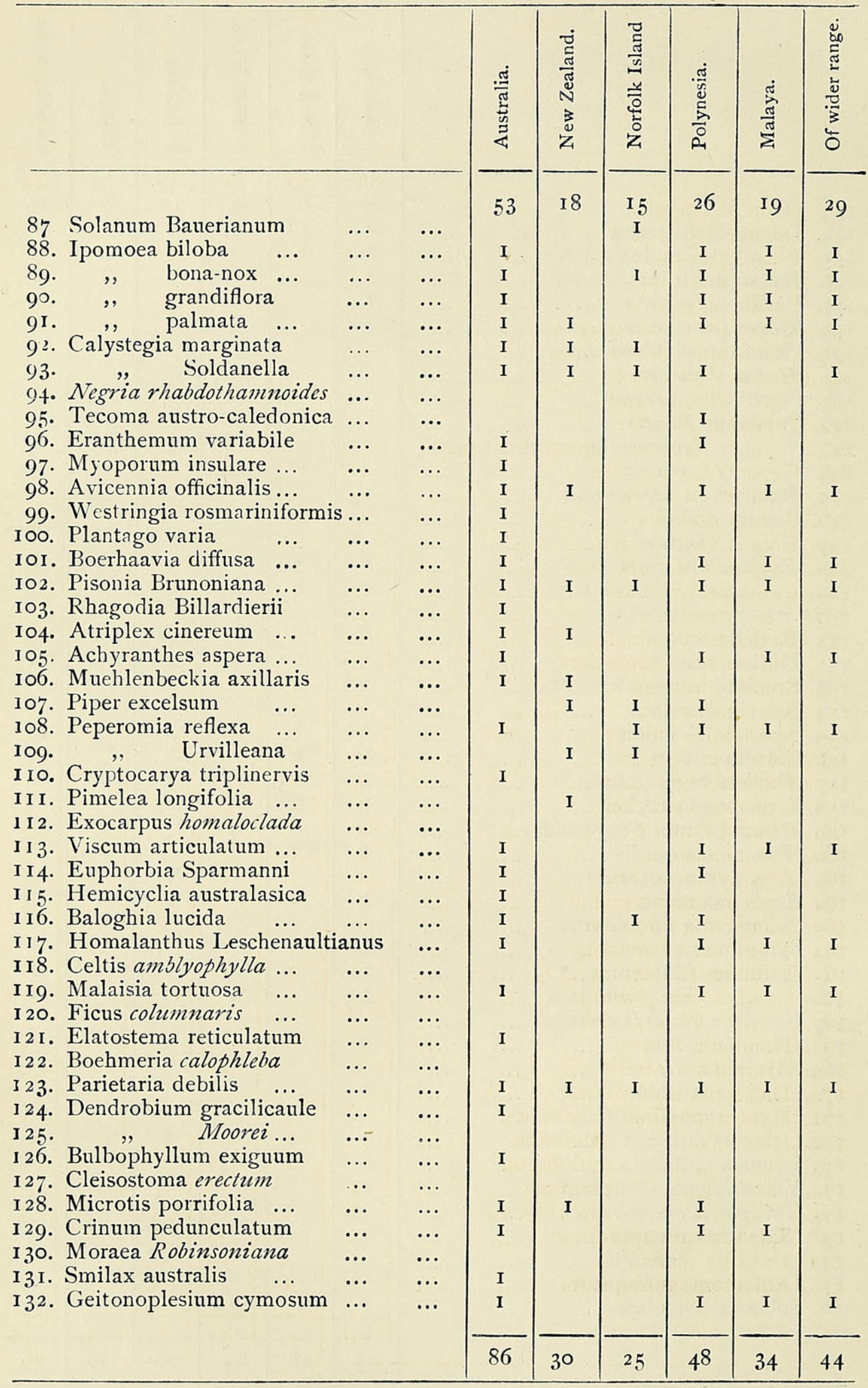




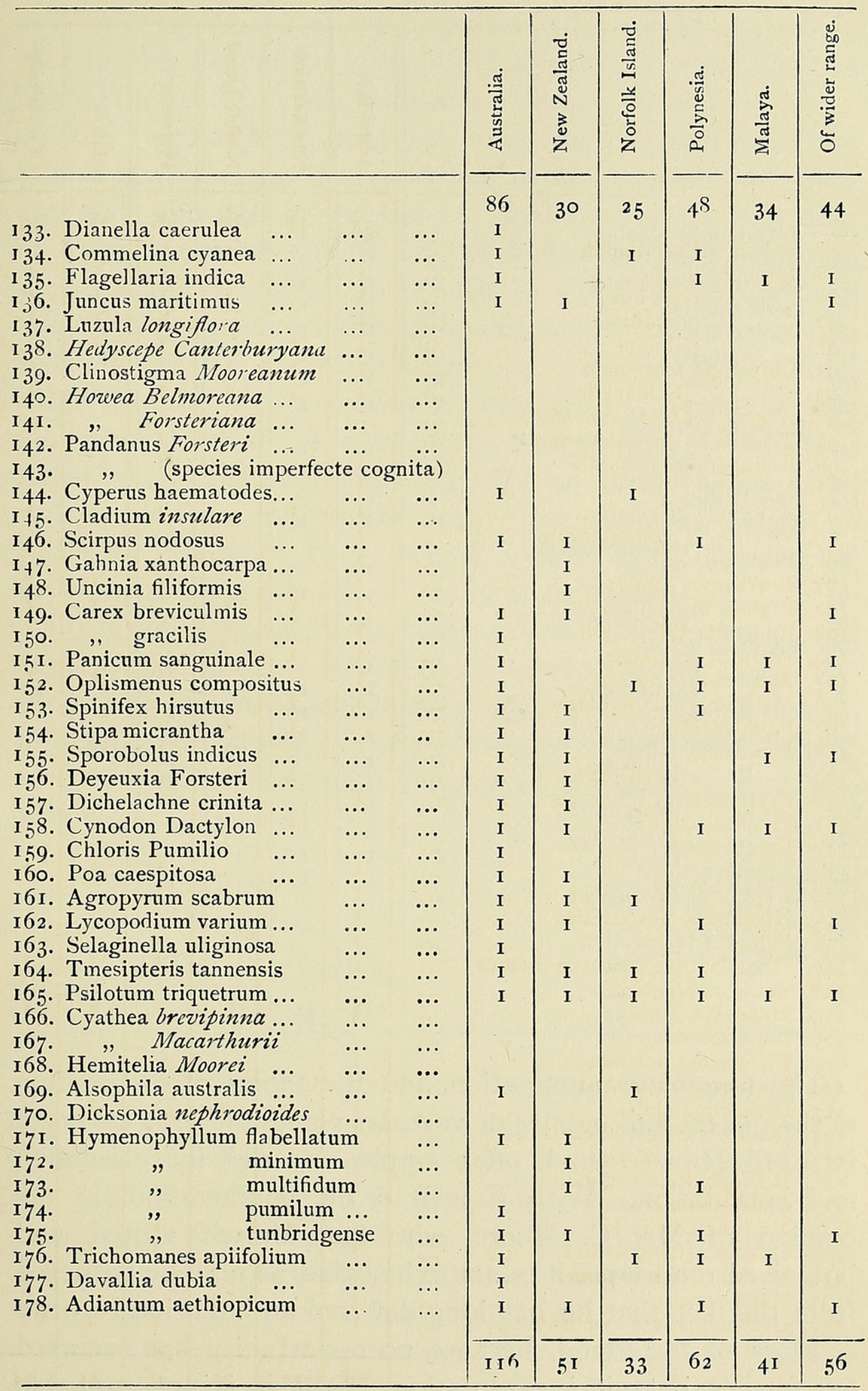




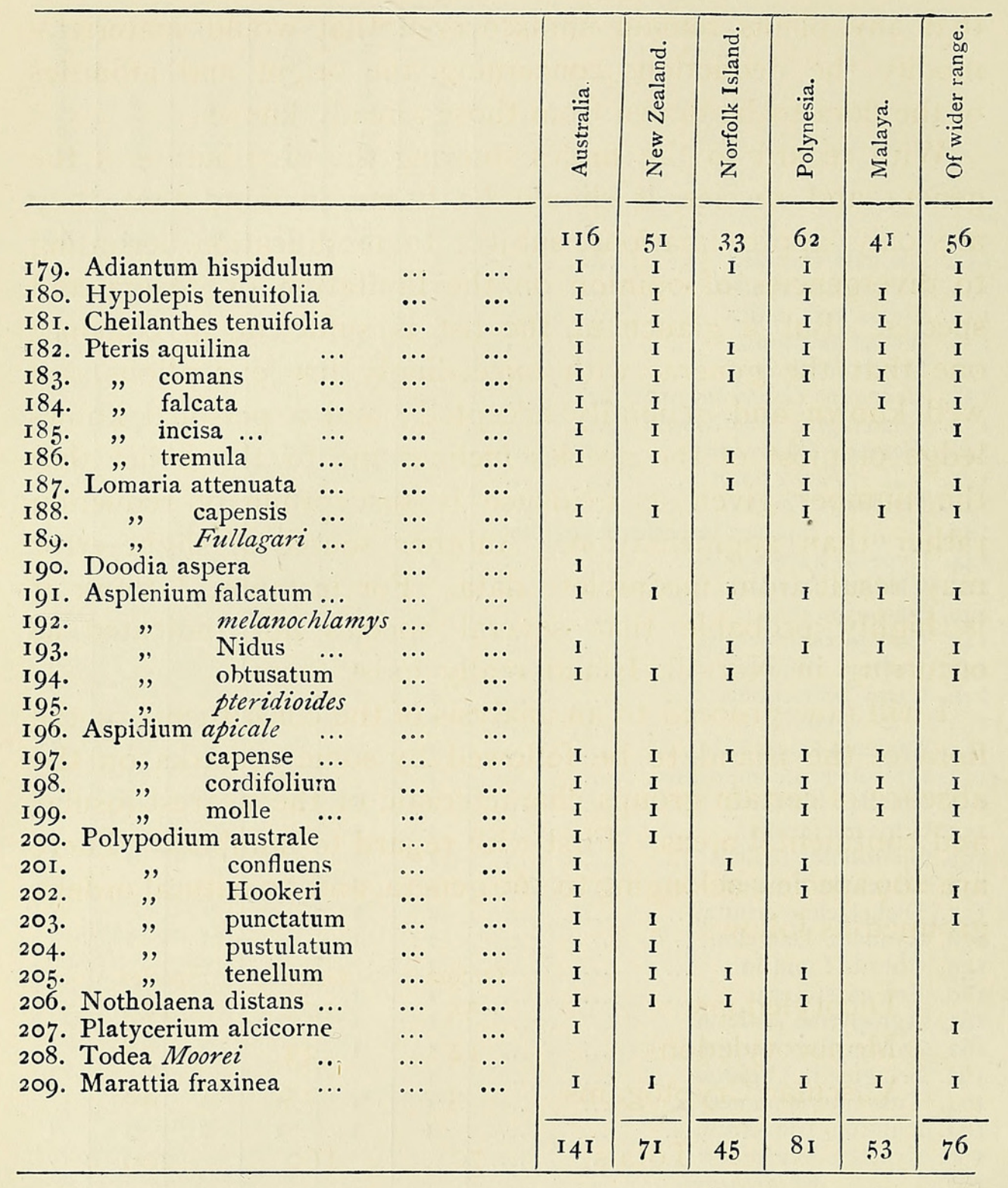

The foregoing enumeration, and the tables of distribution of the genera and species of vascular plants hitherto collected in Lord Howe Island, offer ample material for discussion and speculation. With regard to the enumeration, in the opinion of Mr. C. Moore, who has himself visited and botanized the island, it is not exhaustive, as may be gathered from the fact that he has long deferred an intention to write a Flora of the island, because no opportunity has occurred for further botanical exploration. Still it is not probable 
that any plants remain undiscovered that would materially modify the deductions concerning the origin and affinities of the flora to be drawn from those already known.

With regard to the tables showing the distribution of the genera and species, it should be borne in mind that they are only approximations, subject to modification according to divergencies of opinion on the limitation of genera and species. But a glance at the list is sufficient to convince one that the genera, with exceedingly few exceptions, are well known and generally accepted; and a personal knowledge of most of the species inclines me to the belief that the number given as evidence is susceptible of reduction rather than augmentation. Another source of slight error may result from incomplete data. For instance, I think it is highly probable that several species not indicated as occurring in Norfolk Island really exist there.

I will now proceed to an analysis of the constituents of the flora of the island, to be followed by some remarks on the absence of certain groups characteristic of the nearest insular and continental areas. First with regard to numbers. There are 209 species, belonging to 160 genera, and 70 natural orders, grouped as follows :-

\begin{tabular}{|c|c|c|c|}
\hline Dicotyledons & $\begin{array}{c}\text { Orders. } \\
55\end{array}$ & $\begin{array}{c}\text { Genera. } \\
102\end{array}$ & $\begin{array}{r}\text { Species } \\
123\end{array}$ \\
\hline Monocotyledons & 12 & 33 & $3^{8}$ \\
\hline Vascular Cryptogams & 3 & 25 & 48 \\
\hline Totals & 70 & 160 & 209 \\
\hline
\end{tabular}

There are four endemic genera, namely, Colmeiroa (Saxifragaceae), Negria (Gesneraceae), and Hedyscepe and Howea (Palmae); and there are fifty endemic species, indicated in the table by italics. Of these thirty-three are dicotyledons ; eight monocotyledons, and nine vascular cryptogams. These statistics reveal the phenomena characteristic of remote insular floras; that is to say, a relatively large number of orders and genera in proportion to the number of species; a preponderance of shrubs and trees over herbaceous plants; 
a small number of monocotyledons, especially of the petaloid group, and a considerable endemic element. Among the insular floras that I have worked out, this is most nearly comparable to that of Juan Fernandez; both islands being situated in nearly the same latitude, several hundred miles distant from the nearest land, and rising approximately some 3,000 feet above the sea-level. But the two floras present some singular divergencies in details. Juan Fernandez is more than twice the size of Howe; yet its vascular plants number only 162 species, as against 209 , and of these no fewer than forty-four are ferns. On the other hand, the endemic element in Juan Fernandez is about fifty per cent., or double that of Howe, and arboreous Compositae characteristic of the former, of St. Helena and the Galapagos, are wanting in the latter. They have, however, many features in common, and there are even remote affinities between the two floras. Thus the essentially southern genera Drimys, Coprosma, and Uncinia are represented by different species in the two islands. The only leguminous plant in Juan Fernandez, Sophora tetraptera, is also found in Howe. Lobelia anceps is another plant common to the two islands, but little stress can be laid on this fact, as it probably owes its present wide range to human agency. The Tree-ferns of Juan Fernandez belong to the genera Dicksonia and Alsophila, both represented in Howe, and the solitary endemic palm, Fuania australis, belongs to the Areceae, and is placed very near the genus Howea. The presence of endemic genera of arboreous Compositae in Juan Fernandez, each represented by several species, is the principal distinguishing feature. Yet arboreous Compositae are not wanting in the New Zealand region, Eurybia Traversii and Senecio Huntii being conspicuous trees in the woods of the Chatham Islands, to say nothing of those inhabiting New Zealand itself.

I will now examine a little more in detail the table showing the distribution of the genera of the vascular plants of Howe Island. As we have seen, out of a total of 160 , there are only four endemic. This is a very low percentage, 
considering that thirty per cent. of the Australian, and about 6.5 per cent. of the New Zealand genera are endemic. Ten of the forty-six genera of flowering plants in Juan Fernandez are endemic. In St. Helena the numbers are, total, twentysix and five endemic; and in the more extensive Hawaiian flora fifteen per cent. of the genera are endemic. I may add that the Australian and New Zealand outlying islands generally have very few endemic genera; whereas New Caledonia's remarkably rich flora abounds in endemic genera. Of the Howe Island genera $15 \mathrm{I}$, out of 160 , are Australian; ninety-nine are represented in New Zealand, and sixty-four in Norfolk Island - the last number probably too low. But the most remarkable fact is that no fewer than $\mathrm{I} 34$ of the genera reach the sixth column of the table, which means that they extend in some direction, or directions, beyond the Australasian, Polynesian, and Malay Archipelago regions-these regions taken in their widest sense. Some of the genera, indeed many of them, are of world-wide range; but I do not intend following up their full distribution. What is more remarkable, is the smallness of the number of purely Australasian genera, which do not exceed a dozen; they are: Hymenanthera, a shrubby genus of Violaceae; Lagunaria (Malvaceae); Melicope (Rutaceae), but this also extends to Polynesia ; Carmichaelia (Leguminosae), otherwise restricted to New Zealand; Acicalyptus (Myrtaceae), New Caledonia and Fiji; Cassinia Brachycome, and Olearia (Compositae); Notelaca (Oleaceae); Lyonsia (Apocynaceae); Westringia (Labiatae) and Dichelachne (Gramineae). It will be noticed that the specially characteristic Australasian genera are not represented in Howe Island.

Respecting other genera, I may mention that the supposed African Myoporum has been described as a new genus (Zombiana) by Baillon, and the Madagascar plant referred to Exocarpus turns out to be Leguminosae,-Phylloxylon, Baill., Neobaronia, Baker. Ficus is not represented in New Zealand, and, so far as is known, not in Norfolk Island. It is also worthy of note that the world-wide genus Funcus 
has not been found in the whole of Polynesia, if we except New Caledonia; but Luzula reaches the Sandwich Islands. Passing to the table showing the distribution of the Howe Island species, the total number, as already pointed out, is large for a remote island; yet the endemic percentage is low, both as compared with other less isolated islands and continental areas of greater extent. As compared with a similar area, say, in the South of England, the number of species is decidedly small; but it should be remembered that the increase in the number of species is in the inverse ratio to the increase of area. Thus a single county of England contains something approaching two-thirds of the species found in the whole of the counties.

The most interesting point in the distribution of the nonendemic species of Howe Island is their extensions beyond the island. Leaving out the sporiferous plants, 55 out of I 60 have a wide distribution; including the sporiferous plants, 79 out of 209; and this number includes only a small proportion of the plants known to be dispersed by oceanic currents and birds. Taking those species which do not extend beyond the countries indicated in the first three columns, namely, Australia, New Zealand, and Norfolk Island, we find that thirty-one are found elsewhere only in Australia; five only in New Zealand; three only in Norfolk Island; twelve only in Australia and New Zealand combined; four only in Australia and Norfolk Island; one only in New Zealand and Norfolk Island; and four extend to Australia, New Zealand, and Norfolk Island, but are not found elsewhere. Adding these fifty-eight to the fifty endemic species, we have something more than half of the total coming under the head of what I should term Australasian species. The proportion of Australasian species would be slightly augmented by leaving the Ferns out of the calculation, as Ferns generally have a wider range than flowering plants. The total number of known extensions ${ }^{1}$ to Australia is 142 ; to New Zealand,

\footnotetext{
1 I use the word 'extension' here in a conventional sense, of course; not in the
} sense of the island being the centre from which the plants have actually spread. 
72 ; to Norfolk Island, 39 ; to Polynesia, 82; to the Malay Archipelago, 54; and the extensions beyond the countries named, 79.

Now a few facts with regard to the absence of certain elements from the flora. It has already been mentioned that few of the plants known from actual observation to be dispersed by ocean currents and birds are found in the island. All the Leguminosae in the island, however, with the exception, perhaps, of the Carmichaelia, belong to this category, as well as several species of Ipomoea. The characteristic shrubs and trees of tropical and subtropical Polynesia, such as Thespesia, Pemphis, Barringtonia, Suriana, Guettarda, Morinda, Cordia, and Tournefortia are wholly absent. Gymnosperms and Proteaceae are unrepresented, though both are present in New Zealand and Norfolk Island. The commonest Australian types, abundant in Tasmania, such as Euculyptus, Acacia, and Casuarina, are wanting here, as they are also in New Zealand. The liliaceous genus Cordyline, a conspicuous feature in New Zealand, Tasmania, Australia, and Norfolk Island, though not restricted to these countries, might have been expected to occur. Equally singular is the absence of Ranunculus, Epilobium, and Veronica, genera of worldwide distribution, so copiously developed in New Zealand, where they are exceedingly numerous in species, and not uncommon in Australia, alike in lower latitudes and lower altitudes. Poverty in Leguminosae it shares in common with New Zealand, Norfolk Island, and the distant Juan Fernandez and St. Helena, to say nothing of the numerous smaller southern islands. I might continue these comparisons, but enough has been said to give an idea of the composition of this peculiar small flora, the affinities of which are somewhat complex. The endemic element in this, as in so many other insular floras, has been much over-estimated by some writers, and this has often led to false or improbable deductions. After eliminating all plants likely to have been introduced, accidentally or intentionally, the specific endemic element does not exceed 25 per cent., whereas in New 
Zealand, West Australia, South Africa, and other countries it ranges from 60 to 85 per cent. Yet it has been objected that a former land-connexion between New Zealand and Howe Island was improbable on account of the endemic character of the flora of the latter. This is the view taken by Drude. Tchihatchef states that the flora has little affinity with that of Australia, and belongs to the same centre as Norfolk Island. Wallace, Engler, and others favour a considerable former land-connexion in this region; and looking at the statistics, and the mixed character of the flora, when considered in connexion with that of New Zealand, Norfolk Island, and East Australia, this seems the only sound explanation. The figures given, pp. 272-281, make it difficult to decide where the strongest affinities lie, though when we consider the size of the different areas there is little to choose between them. The number of species common to the island and Australia only, is far in excess of those common to the island and to New Zealand and Norfolk Island combined. The next highest in these comparisons is the number common to the island and to Australia and New Zealand combined. Still we cannot determine the affinities by mere numbers.

As to the flora being derived rather than the remains of a former more extensive one, I think the evidence is all in favour of the latter view, or we must suppose a former much more extensive interchange of plants than under existing agencies could possibly take place. For many years I have been collecting evidence bearing on the dispersal of plants, and I think that all the conveying agencies combined are insufficient to account for the present flora of Lord Howe Island.

In conclusion, I may repeat that the prominent features in the vegetation of Howe Island are the Palms, Screw-Pines, Tree-Ferns, and Banyans; and specially noteworthy among the rare endemic plants are Moraea Robinsoniana and Dracophyllum Fitzgeraldi. Excepting the Seychelles, where there is an even greater development of Palms, no other remote 
island is remarkable for its palm-vegetation, apart from the Coco-nut Palm, which is wanting here, as well as in Norfolk Island, where, as well as in New Zealand, there is one endemic species of this family. The extreme rarity of Palms, except the Coco-nut, in Eastern Polynesia, may, however, be due to the hand of man, as the existence of two or three very rare endemic forms suggests.

\section{WORKS CiTED.}

BECCARI, O.-Malesia, i, p. $66 . \quad$ I 877.

Bentham, G.-Flora Australiensis, 7 vols., 8vo. I $863-78$.

Drake del Castillo, E.-Flore de la Polynésie Française, i vol., 8vo, pp. 352. 1893.

Drude, O.-Geographisches Jahrbuch, xv, p. 396. 1892 .

ENDlicher, S. L.-Prodromus Florae Norfolkicae, I vol., 8vo, pp. Ioo. 1833.

ETheridge.-Lord Howe Island ; its Zoology, Geology, and Physical Characters, I vol., $8 \mathrm{vo}$, pp. viii and I 32 , plates Io. 1889 .

Hemsley, W. B.-Report on the Botany of the Voyage of H. M.S. Challenger, I vol., 3 parts. $1884-85$.

The Flora of the Tonga or Friendly Islands, in the Journal of Linnean Society, xxx, pp. I 58-2I 7, plates 9-II. I 894 .

Heward, R.-Biographical Sketch of the late Allan Cunningham, Esq., in Hooker's London Journal of Botany, i, pp. IO7-I 28 . I $84^{2}$.

List of Plants detected on Norfolk Island by Mr. Cunningham that are not enumerated in Endlicher's Prodromus Florae Norfolkicae, in note on Pp. I 2 I-I 24 .

Hillebrand, W.-Flora of the Hawaiian Islands, I vol., 8vo, pp. $673 . \quad$ i 888.

Hooker, J. D.-Handbook of the New Zealand Flora, I vol., 8vo, pp. $79^{8}$. I 864 .

Hunter, J.-An Historical Journal of the Transactions at Port Jackson and Norfolk Island, I vol., 8vo, pp. 525 . I793.

Mac Gillivray, J.--Letters from, Naturalist on H.M.S. Herald, in Hooker's Kew Journal of Botany, vi, pp. $353-363$. 1854 .

MOORE, C.-Sketch of the Vegetation of Lord Howe's Island, 4to, pp. 4. 1869.

M[OORE], C.-Lord Howe's Island, in Gardeners' Chronicle, 1869, p. 968.

MOORE, C.-Remarks on the Botany of Lord Howe's Island in Transactions of the Royal Society of New South Wales, v, pp. 29-34. I872.

Mueller, F. von.-Fragmenta Phytographiae Australis, vols. vii-ix. 1869-1875.

MUeller, F. voN.-Index omnium Insulae Howeanae Plantarum, quas hactenus obtenui, exclusis speciebus certe introductis, in Fragmenta Phytographiae Australis, ix, pp. $7^{6-78 .} \quad 1875$.

Mueller, F. von.-Second Systematic Census of Australian Plants, I vol., $4^{\text {to, }}$ pp. 244. I 889 .

Phillip, A.-The Voyage of, to Botany Bay, I vol., 4to, pp. $298 . \quad$ I 789.

Seemann, B.-Flora Vitiensis, I vol., 4to. $186_{5-73}$. 


\section{Hemsley. - The Flora of Lord Howe Island.}

TAte, R.-On the Affinities of the Florulas of Lord Howe and Norfolk Islands, in Report of the Fourth Meeting of Australasian Association for Advancement of Science, p. 407. I892. (Title only published.)

Tate, R.-On the Floras of Norfolk and Lord Howe Islands, in the Macleay Memorial Volume of Linnean Society of New South Wales, pp. 205-22I. I 893 .

Tchinatchef, P. DE.-Végétation du Globe, ii, p. 797. $\quad$ I 878.

Vollmer, A.-Lord Howe Insel, Pitcairn und Norfolk, in Petermann's Mittheilungen, xli, pp. $72-77 . \quad 1895$.

Wendland, H., and Drude, O.-Palmae Australasicae, in Linnaea, xxxix, pp. I $53^{-2} 3^{8} . \quad 1875$.

White, J.-Journal of a Voyage to New South Wales, I vol., 4to, p. 299. 1790.

Wilson, J. B.-Report on the Present State and Future Prospects of Lord Howe Island, I vol., 4to. With photographs. I 882 .

Geology by H. WiLkinson ; Botany by J. UuFF.

Supplementary Note.-After the manuscript of the foregoing paper had passed into the printer's hands, the Macleay Memorial Volume of the Linnean Society of New South Wales came under my notice. This contains a paper by Professor R. Tate on the same subject, the title of which is given above.

Professor Tate's work has enabled me to make a few corrections, and two or three additions. His distribution-tables differ from mine in many small and unimportant details, in part doubtless owing to the difficulties of synonymy and the publication of incorrect names for some of the plants. I have not thought it desirable to modify or add to my distribution-tables from this source, because I think that in some cases, at least, the distribution given is doubtful, whilst in others it is incomplete. Thus the following Howe plants are recorded from Norfolk Island, though they do not appear in my table:-Drimys Howeana, Metrosideros polymorpha, Viscum articulatum, Euphorbia Sparmanni, Malaisia tortuosa, Microtis porrifolia, Geitonoplesium cymosum, Sporobolus indicus, and Hymenophyllum multifidum. There is no great improbability about any of these, and I have found specimens of the Viscum and Geitonoplesium; but the absence of Drimys and Metrosideros from our collections makes me a little doubtful concerning these two. He further records Lepidium foliosum and Mesembryanthemum aequilaterale from New Zealand, but there are no specimens at Kew. Echinopogon ovatus (Gramineae) and Aspidium decompositum, both common New Zealand and Australian plants, are additions to my list.

I have also been able to add the title of another paper by Mr. C. Moore, previously overlouked by me, and not seen by Professor Tate. In this he deals with the distribution of the genera only of Howe Island plants, and arrives at the conclusion that this island, Norfolk Island, New Zealand, New Caledonia, and some parts of Australia were formerly connected. He mentions the genera Premna and Pipturus. The specimen referred to the former is flowerless and indeterminable; and the latter is probably a slip, and should be Elatostema.-W. B. H. 


\section{$2 \mathrm{BHL}$ Biodiversity Heritage Library}

Hemsley, W. Botting. 1896. "The flora of Lord Howe island." Annals of botany 10, 221-284. https://doi.org/10.1093/oxfordjournals.aob.a088610.

View This Item Online: https://www.biodiversitylibrary.org/item/235772

DOI: https://doi.org/10.1093/oxfordjournals.aob.a088610

Permalink: https://www.biodiversitylibrary.org/partpdf/318422

\section{Holding Institution}

Smithsonian Libraries

\section{Sponsored by}

Biodiversity Heritage Library

\section{Copyright \& Reuse}

Copyright Status: Not in copyright. The BHL knows of no copyright restrictions on this item.

This document was created from content at the Biodiversity Heritage Library, the world's largest open access digital library for biodiversity literature and archives. Visit BHL at https://www.biodiversitylibrary.org. 